\title{
In silico analysis on the functional and structural impact of Rad50 mutations involved in DNA strand break repair
}

\author{
Juwairiah Remali ${ }^{1}$, Wan Mohd Aizat ${ }^{2}$, Chyan Leong Ng $^{2}$, Yi Chieh Lim ${ }^{3}$, Zeti-Azura Mohamed-Hussein ${ }^{2,4}$, Shazrul \\ Fazry ${ }^{\text {Corresp. 1, } 5}$ \\ ${ }^{1}$ Department of Food Sciences, Faculty of Science and Technology, Universiti Kebangsaan Malaysia, Bangi, Selangor, Malaysia \\ 2 Institute of Systems Biology (INBIOSIS), Universiti Kebangsaan Malaysia, Bangi, Selangor, Malaysia \\ 3 dKDanish Cancer Society, Research Centre Strand Boulevard, Copenhagen, Denmark \\ 4 Department of Applied Physics, Faculty of Science and Technology, Universiti Kebangsaan Malaysia, Bangi, Selangor, Malaysia \\ 5 Pusat Penyelidikan Tasik Chini, Fakulti Sains dan Teknologi, Universiti Kebangsaan Malaysia, Bangi, Selangor, Malaysia \\ Corresponding Author: Shazrul Fazry \\ Email address: shazrul@ukm.edu.my
}

Background. DNA double strand break repair is important to preserve the fidelity of our genetic makeup after DNA damage. Rad50 is one of the components in MRN complex important for DNA repair mechanism. Rad50 mutations can lead to microcephaly, mental retardation and growth retardation in human. However, Rad50 mutations in human and other organisms have never been gathered and heuristically compared for their deleterious effects. It is important to assess the conserved region in Rad50 and its homolog to identify vital mutations that can affect functions of the protein.

Method. In this study, Rad50 mutations were retrieved from SNPeffect 4.0 database and literature. Each of the mutations was analysed using various bioinformatic analyses such as PredictSNP, MutPred, SNPeffect 4.0, I-Mutant and MuPro to identify its impact on molecular mechanism, biological function and protein stability, respectively.

Results. We identified 103 mostly occurred mutations in the Rad50 protein domains and motifs, which only 42 mutations were classified as most deleterious. These mutations are mainly situated at the specific motifs such as Walker A, Q-loop, Walker B, D-loop and signature motif of the Rad50 protein. Some of these mutations were predicted to negatively affect several important functional sites that play important roles in DNA repair mechanism and cell cycle signalling pathway, highlighting Rad50 crucial role in this process. Interestingly, mutations located at non-conserved regions were predicted to have neutral/non-damaging effects, in contrast with previous experimental studies that showed deleterious effects. This suggests that software used in this study may have limitations in predicting mutations in non-conserved regions, implying further improvement in their algorithm is needed. In conclusion, this study reveals the priority of acid substitution associated with the genetic disorders. This finding highlights the vital roles of certain residues such as K42E, C681A/S, CC684R/S, S1202R, E1232Q and D1238N/A located in Rad50 conserved regions, which can be considered for a more targeted future studies. 


\section{In silico analysis on the functional and structural}

2 impact of Rad50 mutations involved in DNA strand 3 break repair

${ }^{1}$ Department of Food Sciences, Faculty of Science and Technology, Universiti Kebangsaan Juwairiah Remali ${ }^{1}$, Wan Mohd Aizat ${ }^{2}$, Chyan Leong $\mathrm{Ng}^{2}$, Yi Chieh Lim ${ }^{3}$, Zeti-Azura MohamedHussein ${ }^{2,4}$, and Shazrul Fazry ${ }^{1,5, *}$

${ }^{2}$ Institute of Systems Biology (INBIOSIS), Universiti Kebangsaan Malaysia, Bangi, Selangor,

Corresponding Authors:

\section{Shazrul Fazry}

Department of Food Sciences, Faculty of Science and Technology, Universiti Kebangsaan Malaysia, Bangi, Selangor, Malaysia Email address: shazrul@ukm.edu.my

\section{Abstract}

Background. DNA double strand break repair is important to preserve the fidelity of our genetic makeup after DNA damage. Rad50 is one of the components in MRN complex important for DNA repair mechanism. Rad50 mutations can lead to microcephaly, mental retardation and growth retardation in human. However, Rad50 mutations in human and other organisms have never been gathered and heuristically compared for their deleterious effects. It is important to assess the conserved region in Rad50 and its homolog to identify vital mutations that can affect functions of the protein.

Method. In this study, Rad50 mutations were retrieved from SNPeffect 4.0 database and literature. 
38 Each of the mutations was analysed using various bioinformatic analyses such as PredictSNP,

39

40

41

42

43

44

45

46

47

48

49

50

51

52

53

54

55

56

57

58

59

60

61

62

63

64

65

66

67

68

69

70

71

72

73

74

75

76

77 biological function and protein stability, respectively.

Results. We identified 103 mostly occurred mutations in the Rad50 protein domains and motifs, which only 42 mutations were classified as most deleterious. These mutations are mainly situated at the specific motifs such as Walker A, Q-loop, Walker B, D-loop and signature motif of the Rad50 protein. Some of these mutations were predicted to negatively affect several important functional sites that play important roles in DNA repair mechanism and cell cycle signalling pathway, highlighting Rad50 crucial role in this process. Interestingly, mutations located at non-conserved regions were predicted to have neutral/non-damaging effects, in contrast with previous experimental studies that showed deleterious effects. This suggests that software used in this study may have limitations in predicting mutations in non-conserved regions, implying further improvement in their algorithm is needed. In conclusion, this study reveals the priority of acid substitution associated with the genetic disorders. This finding highlights the vital roles of certain residues such as K42E, C681A/S, CC684R/S, S1202R, E1232Q and D1238N/A located in Rad50 conserved regions, which can be considered for a more targeted future studies.

Keywords: $\operatorname{Rad} 50, \operatorname{Rad} 50$ related diseases, DNA damage, $\operatorname{Rad} 50$ mutation, $\operatorname{Rad} 50$ in silico model

\section{Introduction}

DNA repair process exists in all organisms including both prokaryotes and eukaryotes, and most of the related proteins in this process are known to be highly conserved throughout biological evolution. One of such protein complexes involved in eukaryotic DNA repair process is MRN complex and it comprises of three proteins i.e. meiotic recombination 11 (Mre11), DNA repair protein Rad50, and nibrin (called Nbn or Nbs1). These proteins play an important role in maintaining the genomic integrity by orchestrating DNA damage checkpoint, telomere maintenance, homologous recombination (HR) as well as non-homologous end joining repair (NHEJ) mechanism (van den Bosch, Bree \& Lowndes, 2003). MRN complex is one of the first factors to be localised to DNA lesions where it has a structural role by tethering and stabilising broken chromosomes (de Jager et al., 2001; van den Bosch, Bree \& Lowndes, 2003).

Null mutations in MRN complex have been shown to be lethal in higher eukaryotes such as in embryonic stem cells (Luo et al., 1999). In addition, mutations in the Nbs 1 gene, can cause Nijmegen breakage syndrome (NBS) whereas Mre11 mutations resulted in Ataxia telangiectasialike disease syndrome (ATLD) (Carney et al., 1998). So far, studies of Nbs1 and Mre11 deficiencies in human have been extensively investigated through cells and clinical data obtained

Peer) reviewing PDF | (2019:04:36390:3:0:NEW 24 Mar 2020) 
78 from NBS and ATLD patients (Barbi et al., 1991; Waltes et al., 2009). Unfortunately 79 investigation of the effect of Rad50 mutations on human is very limited due to only one patient 80 with fully characterized Rad50 deficiency (known as NBS like disorder (NBSLD)) has been 81 reported (Waltes et al., 2009). This NBSLD patient with microcephaly, bird-like features, 82 radiosensitivity and delayed development, revealed to inherit heterozygous mutation from her 83 parents (Barbi et al., 1991). The first mutation (c.3277C/T; p.R1093X) on exon 21 was 84 maternally inherited causing a premature termination codon, thus producing a truncated Rad50 85 protein. Whereas the second mutation on the exon 25 (c.3939A/T) was paternally inherited and it 86 has changed the stop codon of normal Rad50 to a tyrosine codon, thereby producing a larger

87

88

89

90

91

92

93

94

95

96

97

98

99

100

101

102

103

104

105

106

107

108

109

110

111

112

113

114

115

116

117 Rad50 protein (Waltes et al., 2009). Both mutation interestingly give rise to hypomorphic characterization of the Rad50 expressions in this patient (Gatei et al., 2011). The cause of this characteristic are still on debate to this day. Given that perturbation of Rad50 structure and function could contribute to genomic instability (Assenmacher \& Hopfner, 2004), it is therefore important to decipher its conserved domains and genetic polymorphism.

Single nucleotide polymorphism (SNP) is one of the most common types of genetic variation in human (Lee et al., 2005). Even though most of the polymorphic changes do not affect normal cellular function, some variants do influence gene expression or translated protein function (Risch \& Merikangas, 1996; Collins, Guyer \& Charkravarti, 1997). For instance, cystic fibrosis (Bartoszewski et al., 2010), sickle-cell anemia (Shaikho et al., 2017), and $\beta$-thalassemia (Traeger et al., 1980) are examples of diseases resulted from SNPs. Nearly half of the disease-related mutations are derived from nonsynonymous SNPs (nsSNPs), a single base change that alters the amino acid sequence of the encoded protein (Cargill et al., 1999; Halushka et al., 1999). Although it is remarkably important to reveal the connection between SNPs and related diseases, the accelerating number of known SNPs have made it very difficult to discriminate between pathogenic and neutral variants through experimental validations (Tranchevent et al., 2011). Therefore, bioinformatic prediction tools have become extremely critical for the initial analysis of their molecular functions as well as prioritization of further experimental characterization including deciphering the effects of Rad50 SNPs (Bendl et al., 2014). Furthermore, prioritization of disease candidates genes from experiment and databases evidence is essential for further pathological investigation (Piro \& Di Cunto, 2012). Several investigations on Rad50 mutations have been reported in human (Waltes et al., 2009; Gatei et al., 2011), mice (Bender et al., 2002; Roset et al., 2014), yeast (Alani, Padmore \& Kleckner, 1990; Chen et al., 2005), and archaea (Koroleva et al., 2007) yet there are still no reports that compare these experimental results with in silico prediction, which will be important for the protein functional annotation. Moreover, a number of different SNPs for Rad50 have been deposited in SNP databases but their impact on the cellular regulation have not been thoroughly investigated thus far.

Hence, the aim of this study was to identify the functional and structural effects of amino acid mutations in Rad50 gathered from exhaustive literature review and SNP database (SNPeffect 
118 4.0) search. Rad50 sequences in different organisms including human and selected animals 119 (chimpanzee, rats, mice, zebra fish, rabbit and fruit fly) and yeasts were compared and aligned to 120 identify their conserved residues. Mutations that contributed to the most damaging effects were 121 then analysed in silico using PredictSNP for the amino acid impact after the substitution, 122 MutPred for predicting molecular mechanism, SNPeffect for identification of protein or amyloid 123 aggregation as well as I-Mutant and MuPro for protein stability after the mutation. Such approach was also successfully reported by several researchers studying the impact of various

125

126

127

128

129

130

131

132

133

134

135

136

137

138

139

140

141

142

143

144

145

146

147

148

149

150

151

152

153

154

155

156

157 SNPs. For example, Marín-Martín et al., (2014) studied the impact of SNPs in the ABCA1 transporter gene by cross validating their prediction with experimentally reported data. Another study by Fawzy et al., (2015) also validated their in silico approach finding by means of comparison with available literature to study gene polymorphisms in obese children and adolescents. In this study, Rad50 mutations gathered from various studies are compared with their in silico predictions. This is highly valuable in understanding Rad50 functional roles especially during DNA strand break, allowing prioritization of mutations or sites to be studied in future in vivo studies, whilst bearing in mind its possible impact on human. Ultimately, this may help on the development of precision medicine for Rad50 mutations in human.

\section{Materials \& Methods}

\section{Multiple sequence alignment (MSA) analysis and conserved domain analyses}

Human Rad50 protein sequence was obtained from National Center for Biotechnology Information (NCBI). The sequence similarity search tool, BLASTP from the NCBI server (http://blast.ncbi.nlm.nih.gov/Blast.cgi) was used to find homologs for Rad50. To investigate the similarity between Rad50 protein in human and other organisms such as Danio rerio, Mus musculus, Rattus norvegicus, Pan troglodytes, Oryctolagus cuniculus, Drosophila melanogaster, Saccharomyces cerevisiae and Schizosaccharomyces pombe, a multiple sequence analysis (MSA) was conducted using Clustal Omega (https://www.ebi.ac.uk/Tools/msa/clustalo/) with default settings to determine consensus and conserved regions between the multiple sequences of different organisms (Sievers \& Higgins, 2018). Meanwhile, InterPro (http://www.ebi.ac.uk/interpro/) was used to identify the domains and motifs using human sequence (Finn et al., 2017). InterPro results are classified into several types (families, domains, motif or sites) depending on the biological entity they represent (Finn et al., 2017). Using this tool, Rad50 protein sequence was classified into families and the presence of domains and important sites were predicted. ClustalX software (Thompson, Gibson \& Higgins, 2002) was used to view and analyse the conserved regions within the domains and motifs in the selected proteins. 
158

159

160

161

162

163

164

165

166

167

168

169

170

171

172

173

174

175

176

177

178

179

180

181

182

183

184

185

186

187

188

189

190

191

192

193

194

195

196

\section{Data mining of Rad50 mutation from literature and SNPs database}

Rad50 mutations were identified from previous published manuscripts using PubMed database and their functional impacts were extracted for comparison. Besides that, naturally occurring single nucleotide polymorphisms (SNPs) in Rad50 were retrieved from SNPeffect 4.0 database (http://snpeffect.switchlab.org/about) (De Baets et al., 2012) (date of access: April 07th 2018). SNPeffect 4.0 database currently contains more than 60,000 human SNPs gathered from human avariance list available at UniProt website (https://www.uniprot.org/). It specifically focuses on the molecular characterization, annotation of diseases as well as polymorphism variants in human proteins (De Baets et al., 2012). All these available Rad50 protein mutations (obtained from both literature and databases) have been aligned using pairwise alignment through Clustal Omega between human sequence and other organisms' sequence, individually. From this analysis, we identified similar mutation sites in human. All the identified equivalent mutations in human were manually refined, for example removing the same residues and mutations that has been studied by several different researchers to identify the non-redundant mutations (S1 Table). Identified mutations (after converting to equivalent residues in human) were then mapped into Fig. S1.

\section{Secondary structure prediction and analysis of 3D modeling}

The Rad50 templates identified from the BLAST analysis also were used to develop secondary structure and 3D model. The PSIPRED program (http://bioinf.cs.ucl.ac.uk/psipred/) has been utilised for secondary protein structure prediction (Buchan et al., 2013). Secondary structure prediction has revealed a clear distribution of alpha helix, beta sheet and coil in H. sapiens (Helix: 74.69\%, coil; 18.29 and beta sheet; 7.01\% (S2 Figure). Databases such as UniProt (https://www.uniprot.org/) and Protein Data Bank (PDB) (https://www.rcsb.org/) were used to identify structural information regarding Rad50 protein in human. Rad50 protein sequence also has been BLAST searched against Protein Data Bank (PDB) sequence in Network Protein Sequence@nalysis (NPS@) (https://npsa-prabi.ibcp.fr/) to identify the most identical structure. The incomplete structure has been further predicted using fold recognition method using Protein Homology/analogY Recognition Engine Version $2.0 \quad$ (Phyre2) (http://www.sbg.bio.ic.ac.uk/phyre2) (Kelley et al., 2015). Phyre2 is an online tool to predict and analyze protein structure, function and mutations which uses advanced remote homology detection methods to build 3D models, predict ligand binding sites and analyze the effect of amino acid variants (e.g., nonsynonymous SNPs (nsSNPs)) for a protein sequence (Kelley et al., 2015). Rad50 sequence was submitted to the webserver to interpret the secondary and tertiary structures of the model, domain composition and quality. 3D model of Rad50 was run under 'intensive' mode that generates a complete full-length model of a protein sequence by using multiple template modelling and simplified ab initio folding simulation (Kelley et al., 2015). 
197 UCSF Chimera software was used to view and to analyse the 3D structure (Pettersen et al., 198 2004).

199

200

201

202

\section{Prediction of deleterious effects of Rad50 mutations using in silico tools}

203

The Rad50 mutations were in silico predicted using PredictSNP to determine their possible molecular impacts in human (https://loschmidt.chemi.muni.cz/predictsnp1/) (Bendl et al., 2014).

204 Its benchmark dataset contains over 43,000 mutations obtained from the Protein Mutant

205

206

207

208

209

210

211

212

213

214

215

216

217

218

219

220

221

222

223

224

225

226

227

228

229

230

231

232

233

234

235

236 Database and the UniProt database (Bendl et al., 2014). This tool incorporated six established prediction tools; such as Multivariate Analysis of Protein Polymorphism (MAPP) (Stone \& Sidow, 2005), Predictor of human Deleterious Single Nucleotide Polymorphisms (PhD-SNP) (Capriotti \& Fariselli, 2017), PolyPhen-1 (Ramensky, 2002), PolyPhen-2 (Adzhubei, Jordan \& Sunyaev, 2013), Sorting Intolerant from Tolerant (SIFT) (Sim et al., 2012) and SingleNucleotide Amplified Polymorphisms (SNAP) (Bromberg \& Rost, 2007) to provide a more accurate and robust comparison. We classified the mutations as deleterious if five to seven analyses performed were identified as damaging in PredictSNP. For instance, an in silico prediction was considered accurate when a given mutation predicted to be deleterious (as performed in this study) was also found experimentally deleterious (either in vitro or in vivo with phenotypes such as embryonic lethality, growth defect and/or cancer predisposition) based on previous cited studies. Conversely, the prediction is inaccurate if such deleterious mutations was predicted as neutral or tolerant.

\section{Molecular mechanism of amino acid substitutions}

To determine the molecular mechanism based on pathogenicity of amino acid substitutions in Rad50, MutPred2 (Pejaver et al., 2017) (http://mutpred2.mutdb.org/index.html) analysis was carried out. This program predicts the pathogenicity and molecular impacts of amino acid substitutions potentially affecting the phenotype. It is trained on a set of 53,180 pathogenic and 206,946 unlabelled (putatively neutral) variants obtained from the Human Gene Mutation Database (HGMD) (Stenson et al., 2017), SwissVar (Mottaz et al., 2010), dbSNP (Sherry, 2001) and inter-species pairwise alignment (Pejaver et al., 2017). The output of MutPred contains a general probability that the amino acid substitution is deleterious/disease-associated, and a list of rank of specific molecular alterations potentially affecting the phenotype with its $p$-value $(<0.05)$.

\section{Prediction of molecular and structural effects of protein coding variants in Rad50 mutation}

Prediction of molecular and structural effects of protein coding variants in Rad50 mutations was performed using SNPeffect4.0 (De Baets et al., 2012) (http://snpeffect.switchlab.org/about). The analysis includes predictions of the aggregation prone regions in a protein sequence (TANGO), 
237

238

239

240

241

242

243

244

245

246

247

248

249

250

251

252

253

254

255

256

257

258

259

260

261

262

263

264

265

266

267

268

269

270

271

272

273

274

275

276

amyloid-forming regions (WALTZ) and chaperone binding site (LIMBO). The range of prediction score differences outside -50 to 50 for mutants are considered significant (De Baets et al., 2012). SNPeffect also uses FoldX (Schymkowitz et al., 2005) to analyse the effect of mutations on the structural stability. However, as structure quality is important for the accuracy of delta $G$ predictions for stability, model structures with less than $90 \%$ sequence identity to the modelling template structure will not be modelled (De Baets et al., 2012).

\section{Analysis of protein stability}

The stability of Rad50 upon single amino acid residue mutations were predicted using MUpro (http://mupro.proteomics.ics.uci.edu/) (Cheng, Randall \& Baldi, 2006) and I-Mutant 3.0 (http://gpcr2.biocomp.unibo.it/cgi/predictors/I-Mutant3.0/I-Mutant3.0.cgi) (Capriotti, Fariselli \& Casadio, 2005) using default setting, for instance temperature was set at $25^{\circ} \mathrm{C}$ and $\mathrm{pH} 7 . \mathrm{Mu}-$ Pro and I-Mutant 3.0 are valuable tools for protein stability prediction and analysis, even when the protein structure is not yet known with atomic resolution. Both use support vector machines (SVM)-based tool to predict protein stability changes for single amino acid mutations either from both sequence or structural information which correctly predicts with over $80 \%$ accuracy using cross validation methods (datasets and experimental) (Capriotti, Fariselli \& Casadio, 2005; Cheng, Randall \& Baldi, 2006). Rad50 protein sequence was searched against the web server and energy changes $(\Delta \Delta \mathrm{G})$ were recorded. Negative value for $\Delta \Delta \mathrm{G}$ represents a decrease in protein stability whereas positive value for $\Delta \Delta \mathrm{G}$ represents an increase in stability.

\section{Results}

\section{Rad50 data acquisition and MSA analysis}

Human Rad50 sequence from NCBI database contains 1312aa with the accession number of AAB07119.1. Sequence homology search of the human Rad50 protein was performed against NCBI nonredundant protein databases $(E$-value $\leq 1 \mathrm{E}-05)$ and the result was downloaded for further analysis. Out of 500 sequences, six sequences were choosen for MSA analysis from diverse organisms such as D. rerio, M. musculus, $R$. norvegicus, P. troglodytes, O. cuniculus, and D. melanogaster. Two sequences, Saccharomyces cerevisiae and Schizosaccharomyces pombe were also included due to widely being used as models in previous Rad50 studies (S1 Table).

\section{Analysis of protein domains}

Domain identification analysis showed that Rad50 contains three P-loop containing nucleoside triphosphate hydrolase (P-loop NTPase) domains which belong to ATP Binding Cassette (ABC) protein superfamily (De La Rosa Metzere Bierlein \& and Scott W. Nelson, 2011). It is located 
277 near the N- and C-terminal, at the residue number of 25-103, 130-227 and 1196-1279 (Figure 278 1a). Residue annotation showed that Rad50 has six specific motifs including Walker A and Q279 loop that are located at the N-terminal whereas Rad50 signature motif, Walker B, D-loop and H280 loop/switch region are located at C terminal (Figure 1a) (De La Rosa Metzere Bierlein \& and 281 Scott W. Nelson, 2011). It also has a domain called zinc hook (635-734aa) located at C-terminal 282 region (Figure 1a) (Hopfner et al., 2002). Multiple sequence alignment (MSA) analysis between 283 human Rad50 and its homologous genes (D. rerio, M. musculus, $R$. norvegicus, P. troglodytes, 284 O. cuniculus, D. melanogaster, S. cerevisiae and $S$. pombe) also revealed that these specific 285 motifs are highly conserved (Figure 1b).

286

287

288

289

290

291

292

293

294

295

296

297

298

299

300

301

302

303

304

305

306

307

308

309

310

311

312

313

314

315

316

\section{Mutation datasets from the literature and database searches}

In order to identify the Rad50 mutations, literature pertaining to the topic was exhaustively searched and 18 articles over the period of 1990 to 2017 were identified. All these mutations from different organisms were listed in S1 Table. There are 103 mutations identified which mostly occurred in the protein domains and motifs with various biological effects (S2 Table). In order to obtain equivalent mutations in human, pairwise alignment was performed individually between each organism (D. rerio, M. musculus, $R$. norvegicus, $P$. troglodytes, $O$. cuniculus, $D$. melanogaster, $S$. cerevisiae and $S$. pombe) and the Rad50 human sequence as a reference (S1 Table). Then, MSA analysis was carried out between these sequences from different organisms (including human) to identify consensus regions (Figure 1 and S1). Further refinement such as integrating similar mutations that occurred at the same positions (for examples; S1202R, K42R, S679R, P682E, V683R, R1214E, K6E, and R81I (S2 Table) from different organisms of which a total of 80 different mutations or non-redundant mutation were identified. All these mutations have been mapped based on equivalent residues in human (S1 Figure). From SNPeffect 4.0 database, another 13 SNP mutations were also identified (S3 Table). However, from the total of 103 mutations obtained from literature, only 42 residues of the Rad50 protein mutations were known to contribute to the most damaging effects in vitro and in vivo such as embryonic lethality (Bender et al., 2002; Roset et al., 2014) and growth defect (Table 1 and S2 Table) (Alani, Padmore \& Kleckner, 1990; Bhaskara et al., 2007; Waltes et al., 2009; He et al., 2012; Barfoot et al., 2015; Hohl et al., 2015). Most of these deleterious mutations reside at the specific motifs such as Walker A, Q-loop, zinc hook, Rad50 signature motif, Walker B and D-loop (Figure 1b) that become our primary research focus (Figure 1b).

\section{D structure modelling of Rad50}

Currently there is no complete structure of human Rad50 available. Nonetheless, a crystal structure of Rad50 hook and coil-coil domain (HCC) that contains 182 residues (residue 585766) has been determined (PDB ID: 5GOX) (Park et al., 2017), which represents 13\% of the 
317 Rad50 structure in human. We attempted to predict a more complete human Rad50 3D structure 318 model using homology modeling. Homology modeling program Phyre2 successfully predict the 319 N-terminal of 276 residues (2-278) and C-terminal of 155 residues (1153-1306) of human Rad50 320 with 100\% confidence level using the template model (PDB ID: 5DAC) from Chaetomium 321 thermophilum (Seifert et al., 2016) that share 66\% sequence identity (S2 Figure). As a result, half 322 of human $\operatorname{Rad} 50$ protein structure was obtained. The regions with no 3D structure information 323 available are residues 279 to 584 and residues 767 to 1152 (S2 Figure), which were mainly 324 predicted to consist of alpha helices secondary structure (S2 Figure). Pairwise alignment of 325 Rad50 sequence between $C$. thermophilum (1315aa) and human (1312aa) showed about 30\% 326 sequence identity (S2 Figure). The result showed that the partial structure of C. thermophilum 327 that has been determined (black line) are highly conserved with the human sequence (S2 Figure) suggesting that the human structure should also share high structure similarity to $C$.

329

330

331

332

333

334

335

336

337

338

339

340

341

342

343

344

345

346

347

348

349

350

351

352

353

354

355

356

thermophilum at these regions. In agreement to this, results from Phyre 2 prediction showed that the N-terminal and C-terminal of Rad50 form a globular and coil-coil domain, similar to the structure of $C$. thermophilum (Figure 2a). With the generated model, six motifs of Rad50 namely Q-loop, Walker B, signature motif, D-loop, Walker A and H-loop were identified and marked in the 3D structure (Figure 2a). All identified deleterious residues found in the domain were also marked as shown in Figure 2b. To correlate the deleterious residues in the Rad50 HCC domain with zinc hook motif that was not found in the model, the structure of 181 residues (residue 585766) that has been determined (PDB ID: 5GOX) independently was employed (Figure 2c and 2d) for functional analysis.

\section{Analyses of Rad50 mutation deleterious effects}

All of these 42 mutations (based on mutations from other organisms mapped to human) (Figure $1 \mathrm{~b}$ and $2 \mathrm{~b}$ ) were then analysed using bioinformatics analyses such as impact of amino acid substitutions (PredictSNP), molecular mechanism (MutPred), structural phenotyping (protein and amyloid aggregation) (SNPeffect 4.0) and protein stability (MuPro and I-Mutant 3.0) (Table 2). All raw data from each analysis has been supplied as supplementary data (S3 Table for PredictSNP analysis, S4 Table for MutPred analysis, S5 Table for SNPeffect analysis and finally S6 Table for I-Mutant and MuPro analysis). The results showed that most of the deleterious effects fall into specific motifs such as Walker A, Q-loop, Rad50 signature motif, Walker B and D-loop (Table 2 and Figure 2a). Previous analysis also revealed that mutations at these motifs contributed to a number of biological defects such as growth defect (Alani, Padmore \& Kleckner, 1990; He et al., 2012; Hohl et al., 2015) embryonic lethality (Bender et al., 2002; Roset et al., 2014), cancer predisposition (Bender et al., 2002; Roset et al., 2014), hematopoietic and spermatogenic depletion (Bender et al., 2002; Roset et al., 2014) (Table 1). Several mutations at the zinc hook region (C681A, C681S, P682E, C684R and C684S) and ATPase/coiled-coil domain (K6E and K132E) also showed to be deleterious (Table 2, Figure 2c and 2d).

Peer) reviewing PDF | (2019:04:36390:3:0:NEW 24 Mar 2020) 
357 Furthermore, mutations located at Walker A (Figure 2a) were predicted to affect catalytic and

358

359

360

361

362

363

364

365

366

367

368

369

370

371

372

373

374

375

376

377

378

379

380

381

382

383

384

385

386

387

388

389

390

391

392

393

394

395

allosteric site, loss or gain of methylation, alteration of DNA binding, metal binding, ordered interface and the loss of relative solvent accessibility, which all are depending on the types of amino acid substitutions (Table 2). These mutations were predicted to affect ATP binding site motif, N-myristolylation, casein kinase II (CK2), protein kinase A (PKA) phosphorylation site and Forkhead-associated (FHA) functional sites. Mutations at the Walker A region also might led to the decrement of protein stability as predicted by I-Mutant and MuPro. Mutation at the Qloop region (Q159H) (Figure 2a and 2b) also predicted to have significant deleterious effect and decreased protein stability, but no effects have been identified on its molecular mechanism and structural phenotyping as predicted by MutPred and SNPeffect 4.0, respectively (Table 2).

Mild deleterious effect was predicted_at the mutated zinc hook domain (Table 2 and Figure 2e). Subsequent analysis using MutPred also revealed that any mutation at zinc hook might affect several important functional sites that involved in DNA damage repair signalling response and cell cycle checkpoints such as phosphatidylinositol 3-kinase-related kinases (PIKK) phosphorylation site, protein kinase $\mathrm{C}$ (PKC) phosphorylation site and BRCA1 C-terminus (BRCT) phosphopeptide ligands binding sites (Table 2). Moreover, deleterious mutation was predicted at the conserved cysteine residue located at the zinc hook motif (CXXC). For example, amino acid substitutions of alanine (A) and serine (S) at the cysteine residue position 681; (C681(A/S)) (Figure 2d) may affect N-glycosylation, proline-directed phosphorylation and mitogen-activated protein kinases (MAPK) phosphorylation site, which possibly due to the affected zinc binding domain (Table 2). Another deleterious mutation, C684(R/S) was also predicted to not affect its molecular mechanism but might disrupt diarginine retention/retrieving signal, PKC and PIKK phosphorylation site (Table 2). Whilst P682E (Figure 2d) mutation may lead to gain of helix, altered coiled coil domain, loss of N-linked glycosylation and CK2 phosphorylation site (Table 2).

Rad50 signature motif (Figure 2a) is a critical site which could lead to deleterious effects if mutated as suggested by PredictSNP analysis (Table 2). All mutations in this motif (S1202A/R/M, Q1205E and K1206M/A/E) or located near this motif (G1198E, L1211W and $\mathrm{R} 1214 \mathrm{~A} / \mathrm{E}$ ) (Figure $1 \mathrm{~b}$ and $-2 \mathrm{~b}$ ) were predicted to affect the protein allosteric and catalytic sites (Table 2), except for R1198E. Mutations at residue S1202A/R/M (Figure 1b and 2b) might affect PKA phosphorylation sites and glycosaminoglycan attachment site (Table 2). Furthermore, R1214A (Figure 1b and 2b) mutation might affect ATP-binding cassette, ABC transporter-type, signature and profile functional sites (Table 2). We have also predicted identified-several mutations in Rad50 signature motif such as Q1205E, L1211W and R1214A that contributed to the total defect in the structural phenotyping such as the increment in protein and amyloid aggregation and the decrement of protein stability (Table 2).

Peer) reviewing PDF | (2019:04:36390:3:0:NEW 24 Mar 2020) 
396 We have also predicted K6E, K132E and K105E mutations occurred at the coil-coiled domain or

397

398

399

400

401

402

403

404

405

406

407

408

409

410

411

412

413

414

415

416

417

418

419

420

421

422

423

424

425

426

427

428

429

430

431

432

433

434

435

ATPase domain to be deleterious (Figure 1b, $2 \mathrm{~b}$ and Table 2). Specifically, the mutations at K6E and K132E might lead to loss of strand or loss of helix, respectively. Additionally mutation at K132E also predicted to affect casein kinase 1 (CK1) and PKC phosphorylation sites (Table 2). Even though K22M and R83I (Figure 2b) were predicted to be neutral in PredictSNP analysis, both of these mutations have also been predicted to increase protein aggregation tendency (Table 2). The mutation at R83I might contributed to the alteration of coiled coil structure domain, DNA binding and ordered interface, that might affect the functional site such as protein-protein interactions (PPI)-docking motif (Table 2). Another neutral mutation predicted were T191E, $\mathrm{C} 221 \mathrm{E}$ and S106E (Figure $1 \mathrm{~b}$ and $2 \mathrm{~b}$ ), where T191E mutation might be responsible in altering the coiled coil domain and may affect tumor necrosis factor receptor-associated factor (TRAF), serine/threonine-protein kinase (NEK2) and PKC phosphorylation site (Table 2). On the other hand, C221E and S106E (Figure $1 \mathrm{~b}$ and $2 \mathrm{~b}$ ) were predicted to not affect any molecular mechanism or protein aggregation (Table 2).

\section{Discussion}

Rad50 is a member of the structural maintenance of chromosomes (SMC) family of proteins that participates in chromosome structural changes (Kinoshita et al., 2009). The globular ABC ATPase head domain is formed by the N- and C-termini (Figure 2a) (Hohl et al., 2011). The coiled-coil apex of Rad50 contains a conserved cysteine amino acid motif across the organisms, which is called the zinc hook (Kinoshita et al., 2009). When DNA double strand break occurs, Rad50 complex binds to the DNA early in the repair process to recognize such breaks and grips them in close juxtaposition (Paull \& Gellert, 1998; de Jager et al., 2001). This protein also activates ATM kinase that is crucial for DNA damage signalling (Uziel et al., 2003).

Rad50 globular head domain contains conserved domains and motifs (Figure 1a and 2a) such as P-loop NTPase domains and six motifs which are Walker A and B motifs, Rad50 signature motif, D-loop, H-loop, and Q-loop motif (Figure 1a and 2a). P-loop NTPase domains are belong to $A B C$ protein superfamily. The $A B C$ protein superfamily has been identified in diverse organisms and is also known to be one of the most conserved protein superfamilies (Jones, O'Mara \& George, 2009). ABC proteins consist of six conserved motifs (Figure 1a and 2a) which make up the nucleotide binding domain in Rad50 (Symington, 2002). The nucleotide binding domain of $\mathrm{ABC}$ protein is known to play an important role in binding and hydrolyzing ATP at its dimeric interface (Davidson et al., 2008). Rad50 also has a special conserved Cys-X$\mathrm{X}$-Cys zinc hook motif at the center of coiled-coil domain (Figure 2c). This motif is in a hookshaped structure which dimerizes a second hook via cysteine-mediated zinc ion coordination (Figure 2c) (Hopfner et al., 2002). This zinc dependent dimerization event allows the formation of MRN complex which has suitable lengths and conformational arrangements to link sister chromatids in HR and DNA ends in NHEJ (Hopfner et al., 2002).

Peer) reviewing PDF | (2019:04:36390:3:0:NEW 24 Mar 2020) 
436

437

438

439

440

441

442

443

444

445

446

447

448

449

450

451

452

453

454

455

456

457

458

459

460

461

462

463

464

465

466

467

468

469

470

471

472

473

474

475

\section{Consistency between bioinformatics prediction and experimental evidence}

PredictSNP was used in this study to provide a more accurate prediction of disease-related mutations as it combines six best performing prediction tools for a consensus classifier (Bendl et al., 2014). Evidently, this in silico analysis was consistent with the results from the previous experimental studies where mutations at the Walker A, D-loop, signature motif, Q-loop and Walker B have shown damaging effects (Table 1, 2 and Figure 2a).

G41D and K40E (Figure $1 \mathrm{~b}$ and 2b) mutations at the Walker A motif (Figure 2a) and C681A and C684R (Figure $1 \mathrm{~b}$ and $2 \mathrm{~d}$ ) mutations at the cysteine residue (CXXC) in the zinc hook motif (Figure 2c) conferred an identical phenotype with the Rad50 null mutation characterized by total defect in the formation of viable spore in S. cerevisiae experiment (Table 1) (Alani, Padmore \& Kleckner, 1990; He et al., 2012). This analysis also identified that mutations at Q-loop (Q159H) and D-loop (D1238N and D1238A) (Figure 1b, 2a and 2b) were also predicted deleterious (Table 2) and were experimentally shown to interrupt all ATP-dependent activities of the complex in different organisms such as P. furiosus and T bacteriophage respectively (Table 1) (Moncalian et al., 2004a; De La Rosa Metzere Bierlein \& and Scott W. Nelson, 2011). Furthermore, a E1232Q (Figure $1 \mathrm{~b}$ and 2b) mutation at the Walker B motif (Figure 2a) was also predicted to be deleterious (Table 2). Similarly the mutation of Walker B at residue E798Q in Thermotoga maritima showed low ability to respond to DNA damage (Table 1) (Rojowska et al., 2014a). This suggests that this motif is important for a molecular repair process, specifically during DNA binding process, which if mutated will affect the viability of an organism. Our analysis using PredictSNP has identified three mutations, which were N28A (Figure 1b and 2b) (De La Rosa Metzere Bierlein \& and Scott W. Nelson, 2011), D1238H (Figure 1b and 2b) (De La Rosa Metzere Bierlein \& and Scott W. Nelson, 2011) and S1202R (Figure 1b and 2b) (Kerem et al., 1989; Moncalian et al., 2004a) located at the Walker A, D-loop and Rad50 signature motif, respectively (Figure 2a) (Kerem et al., 1989; Moncalian et al., 2004a; De La Rosa Metzere Bierlein \& and Scott W. Nelson, 2011).

Mutations at the Walker A domain and Rad50 signature motif (Figure 2a) may also affect important functional sites such as ATP binding site (Table 2). For example, K42R/M/E/A mutation at the Walker A (Figure $1 \mathrm{~b}$ and $2 \mathrm{~b}$ ) in $S$. cerevisiae and $D$. radiodurans has been identified experimentally to cause defective in ATPase (Table 1) (Chen et al., 2005; Koroleva et al., 2007) and S793R mutation in Pyrococcus furiosus showed the inhibition of ATP binding and disrupted communication between ATP loops (Table 1) (Moncalian et al., 2004a). This mutation further distorted the surface of the C-terminal domain and thus altered the interaction between Rad50 monomers to prevent dimerization (Table 1) (Moncalian et al., 2004a). We have also identified mutations at several motifs such as Walker A (G41D, K42M/R/E/A) and Walker B (E1232Q) (Figure 1b, 2a and 2b) that might affect the binding of FHA phosphopeptide ligands

Peer) reviewing PDF | (2019:04:36390:3:0:NEW 24 Mar 2020) 
476 that plays a critical role in DNA damage repair mechanism and cell cycle (Table 2). Many FHA 477 domain-containing proteins localized to the nucleus showed to play a critical role in establishing 478 or maintaining DNA repair, cell cycle checkpoints or transcriptional regulation (Durocher et al., 479 2000). When mutated, diseases such as Nijmegen breakage syndrome (NBS) and the hereditary 480 cancer syndrome variant Li-Fraumeni (CHK2) will be developed (Matsuura et al., 1998; Varon 481 et al., 1998; Carney et al., 1998b; Featherstone \& Jackson, 1998; Bell et al., 1999) suggesting the 482 483

Mutations at or near the Rad50 signature motif (Figure $1 \mathrm{~b}$ and $2 \mathrm{a}$ ) were also known to be damaging (Table 2), particularly the S1202R (Figure $1 \mathrm{~b}$ and $2 \mathrm{~b}$ ) mutation which has been studied the most due to its numerous biological defects in vivo. The same residue mutations of the Rad50 signature motif in yeast (S12025R) and human (S1202R) also generated complexes that were significantly diminished in adenylate kinase (AK) activity that was important for DNA tethering (Bhaskara et al., 2007). Previously, AK deficiency was found to be associated with anaemia and several cases of mental retardation and psychomotor impairment (Abrusci et al., 2007), which may explain why disruption of the MRN complex also causes this phenotype on patients (Waltes et al., 2009). In addition, such deleterious mutation also contributed to inviable spores and significant telomere shortening in S. cerevisiae (Bhaskara et al., 2007). Defects in telomere length in human have been known to cause the pathology of several age-related diseases and premature ageing syndrome, as well as cancer and other human diseases such as Hoyeraal-Hreidarsson syndrome, Coats plus syndrome, pulmonary fibrosis, dyskeratosis congenita, liver fibrosis and aplastic anemia (Blasco, 2005).

Additionally, most mutations such as G1199E, S1202A/R/M, and Q1205E (Figure 1b and 2b) at the Rad50 signature motif (Figure 2a) were identified to affect PKA phosphorylation site (Table 2) suggesting that this site is dependent upon the function of Rad50 signature motif. Phosphorylation is one of the most ubiquitous and important post translational modifications of proteins, and implicated in almost all kinds of cellular processes and pathways (Ptacek \& Snyder, 2006). In neurons, enhanced PKA signalling promotes neuronal development, enhances synaptic plasticity, and elevates dopamine synthesis (Dagda \& Das Banerjee, 2015). However a deterioration in PKA signalling has contributed to the aetiology of several neurodegenerative diseases, such as Alzheimer and Parkinson (Dagda \& Das Banerjee, 2015). We hypothesized that the defective PKA functional sites may also lead to Nijmegen breakage syndrome associated with neurological phenotype in Rad50 mutations (Waltes et al., 2009), however this potential phosphorylation sites remain to be validated.

C681A and C684R mutations (Figure $1 \mathrm{~b}$ and $2 \mathrm{~d}$ ) at the zinc hook motif (Figure 2c) were identified deleterious from our analysis (Table 2) and these mutations were known to lead severe defects in various DNA damage response (DDR) such as ataxia-telangiectasia mutated (ATM) protein activation, homologous recombinant, irradiation sensitivity and ataxia telangiectasia and 
516 Rad3 related (ATR) protein activation (He et al., 2012). These findings were consistent with our 517 bioinformatics analysis where C684S deleterious mutation at zinc hook (Figure 1b and 2d) might 518 affect a protein kinase called ataxia telangiectasia mutated (ATM) that belongs to the 519 phosphatidylinositol 3-kinase-related kinase (PIKK) family (Table 2). The ATM protein was 520 known to cause devastating ataxia-telangiectasia syndrome which is characterized by progressive 521 neurological disorder, impaired organ maturation and immunodeficiency (Shiloh \& Ziv, 2013). 522 Rad50 phosphorylated ATM at S635 site (Figure 1b and 2d) of which the mutation on this site 523 showed its importance for cell cycle control signalling and DNA repair mechanism (Gatei et al., 524 2011).

525

526

527 P682E mutation at the zinc hook motif (Figure $1 \mathrm{~b}$ and 2d) was shown to be deleterious (Table 2), where previous study has reported that the double mutation P682E and S679R at the zinc hook 528 motif have reduced zinc affinity and dimerization efficiency leading to mice lethality (Roset et al., 2014). In addition, crossbreeding P682E and S679R mutant mice with wildtype mice produce offsprings with hydrocephalus (accumulation of cerebrospinal fluid within the brain), defects in hematopoietic stem cells and gametogenic cells. This suggests that the hook motif has strong influence on the MRN complex associated with DDR signalling, tissue homeostasis and

533 tumorigenesis, as well as fertility of the organism (Roset et al., 2014). This is consistent with the mutations in the yeast hook domain that has increased chromosomal fragmentation (Cahill \&

535 Carney, 2007), suggesting its presence is required for the binding or tethering of chromosomal ends.

537

538

\section{Limitations of in silico prediction}

539

540

Several mutations were functionally predicted to be neutral, in contrast with the previous experimental findings. For example, a few mutations i.e. S635G (H. sapiens), S679R, C680N, P682A, V683I (S. cerevisiae), V683R (M. musculus) and Q685S (S. cerevisiae) (Figure 1b and 543 2d) located at the zinc hook domain (Table 2) and mutations on K22M (S. cerevisiae and $M$. 544 musculus), R83I (S. cerevisiae and M. musculus), T191E, C221E and S106E (T. maritima) in the 545 ATPase domain (Figure $1 \mathrm{~b}, 2 \mathrm{~b}$ and Table 2 ) were experimentally validated to be deleterious 546 (some causing embryonic lethality, growth defect, cancer predisposition, as well as 547 hematopoietic and spermatogenic depletion in vivo (Bender et al., 2002). A few previous studies 548 have also shown discrepancies between computer prediction and experimental data. For 549 example, an extensive in silico analysis using PolyPhen2 and MutPred tools of the ATP-binding

550

551

552

553

554

555 cassette transporter ABCA1, an important target in anti-atherosclerosis treatment predicted that several nsSNPs can be neutral, contradicting with previous experimental data findings (MarínMartín et al., 2014). Furthermore, another in silico analysis performed using PolyPhen and SIFT on proteins related to several hereditary diseases such as glucose-6-phosphate dehydrogenase deficiency (G6PD), the receptor 1 for tumor necrosis factor-(TNFRSF1A), and familial mediterranean fever (MEFV) has concluded that some nsSNPs impact may also not be predicted 
556 deleterious to correspond to previous phenotypic effect (Tchernitchko, Goossens \& Wajcman, 557 2004). Moreover, in silico identification of PmrAB virulence targets in Salmonella 558 typhimurium also demonstrated false positive prediction when validated experimentally (Marchal 559 et al., 2004) suggesting that more work has to be done to develop a more accurate bioinformatics 560 prediction platforms in the future. In contrast, various SNP prediction software have predicted 561 that these mutations were not damaging (Table 2).

562

563 Such discrepancy between the computational prediction and experimental results may be due to 564 several limitations in the bioinformatic tools used in our analysis. Several web-based prediction 565 tools may supply conflicting results (Wan et al., 2008) and even with an integrated predictor, 566 PredictSNP (Bendl et al., 2014), it is also limited by the differences in algorithms, principles, 567 training datasets and information used. For example, MAPP, PANTHER and SIFT in the 568 PredictSNP used alignment scores for functional prediction whereas SNAP, PoplyPhen-1 and 569 PolyPhen-2 used neural network, support vector machine and Naïve Bayes algorithm, 570 respectively (Bendl et al., 2014). Interestingly, we identified that the software predicts most 571 accurately (in agreement with experimental results) for the motifs or sites located at the highly 572 conserved position (Figure 1b). Conversely, most residues that were predicted to be neutral are 573 located at non-conserved positions in the Rad50 protein (S3 Figure and S7 Table), suggesting 574 that these prediction software may have only been trained and preferentially biased towards 575 conserved regions (Gardner et al., 2017). This suggests that computer prediction should also 576 consider and take into account the effect of non-conserved regions outside the motifs/domains 577 too for future improvement in their algorithms. Furthermore, any subsequent prediction studies 578 should also be aware of this limitation (whether located in conserved or non-conserved regions)

579

580

581

582

583

584

585

586

587

588

589

590

591

592 This study compiled all mutations to date in Rad50 proteins from various organisms and predicts

593

594

595

to carefully deduce the function of their protein mutation of interest.

Nonetheless, we cannot rule out the possibility that these mutations derived from other organisms may not be readily affected or transferred to other organisms including human. This is because certain organisms may possess gene compensation to compensate or mask the effect of such mutations and that the different proteins from different organisms may not have perfectly superimposable function. Hence, future experiments should focus on their validation especially in human cell line studies to better understand the roles of these mutated residues in Rad50 function.

\section{Conclusions} their effects using various software tools such as PredictSNP, MutPred, SNPeffect, I-Mutant and MUpro. Most predictions for SNPs occurring within conserved regions are in agreement with their corresponding in vivo or in vitro experimental results. However, SNPs located at non- 
596 conserved regions are less likely to be accurately predicted, and as such algorithms for these 597 software should be improved in future studies. Altogether this study has provided means to 598 prioritized mutations particularly in Rad50 protein that have biologically meaningful function for 599 DNA double-stranded maintenance.

600

601

\section{Acknowledgements}

602 The authors would like to acknowledge and thank INBIOSIS and Makmal Genomik 1 research 603 teams from Universiti Kebangsaan Malaysia for their help with laboratory and technical 604 analyses.

605

606

607

608

609

610

611

612

613

614

615

616

617

618

619

620

621

622

623

624

625

626

627

628

629

630

631

632

633

\section{References}

Abrusci, P., Chiarelli, L.R., Galizzi, A., Fermo, E., Bianchi, P., Zanella, A. \& Valentini, G. (2007). Erythrocyte adenylate kinase deficiency: characterization of recombinant mutant forms and relationship with nonspherocytic hemolytic anemia. Experimental Hematology, 35(8): 1182-1189.

Adzhubei, I., Jordan, D.M. \& Sunyaev, S.R. (2013). Predicting functional effect of human missense mutations using PolyPhen-2. Current Protocols in Human Genetics, 7(Supp76) $: 20$.

Alani, E., Padmore, R. \& Kleckner, N. (1990). Analysis of wild-type and rad50 mutants of yeast suggests an intimate relationship between meiotic chromosome synapsis and recombination. Cell, 61(3): 419-436.

Assenmacher, N. \& Hopfner, K.P. (2004). MRE11/RAD50/NBS1: Complex activities. Chromosoma, 113(4): 157-166.

De Baets, G., Van Durme, J., Reumers, J., Maurer-Stroh, S., Vanhee, P., Dopazo, J., Schymkowitz, J. \& Rousseau, F. (2012). SNPeffect 4.0: On-line prediction of molecular and structural effects of protein-coding variants. Nucleic Acids Research, 40(D1): 935-939.

Barbi, G., Scheres, J.M.J.C., Schindler, D., Taalman, R.D.F.M., Rodens, K., Mehnert, K., Müller, M., Seyschab, H., Muller, M. \& Seyschab, H. (1991). Chromosome instability and $\mathrm{X}$-ray hypersensitivity in a microcephalic and growth-retarded child. American Journal of Medical Genetics, 40(1): 44-50.

Bartoszewski, R. a., Jablonsky, M., Bartoszewska, S., Stevenson, L., Dai, Q., Kappes, J., Collawn, J.F. \& Bebok, Z. (2010). A synonymous single nucleotide polymorphism in delta F508 CFTR alters the secondary structure of the mRNA and the expression of the mutant protein. Journal of Biological Chemistry, 285(37): 28741-28748.

Bell, D.W., Varley, J.M., Szydlo, T.E., Kang, D.H., Wahrer, D.C.R., Shannon, K.E., Lubratovich, M., Verselis, S.J., Isselbacher, K.J., Fraumeni, J.F., Birch, J.M., Li, F.P., Garber, J.E. \& Haber, D.A. (1999). Heterozygous germ line hCHK2 mutations in LiFraumeni syndrome. Science, 286(5449): 2528-2531. 
634 Bender, C.F., Sikes, M.L., Sullivan, R., Huye, L.E., Le Beau, M.M., Roth, D.B., Mirzoeva, O.K.,

635

636

637

638

639

640

641

642

643

644

645

646

647

648

649

650

651

652

653

654

655

656

657

658

659

660

661

662

663

664

665

666

667

668

669

670

671

672

673

Oltz, E.M. \& Petrini, J.H.J. (2002). Cancer predisposition and hematopoietic failure in Rad50S/S mice. Genes and Development, 16(17): 2237-2251.

Bendl, J., Stourac, J., Salanda, O., Pavelka, A., Wieben, E.D., Zendulka, J., Brezovsky, J. \& Damborsky, J. (2014). PredictSNP: Robust and Accurate Consensus Classifier for Prediction of Disease-Related Mutations. PLoS Computational Biology, 10(1): 1003440.

Bhaskara, V., Dupr, A., Lengsfeld, B., Hopkins, B.B., Chan, A., Lee, J.H., Zhang, X., Gautier, J., Zakian, V. \& Paull, T.T. (2007). Rad50 Adenylate Kinase Activity Regulates DNA Tethering by Mre11/Rad50 Complexes. Molecular Cell, 25(5): 647-661.

Blasco, M.A. (2005). Telomeres and human disease: Ageing, cancer and beyond. Nature Reviews Genetics, 6(8): 611-622.

van den Bosch, M., Bree, R.T. \& Lowndes, N.F. (2003). The MRN complex: Coordinating and mediating the response to broken chromosomes. EMBO Reports, 4(9): 844-849.

Bromberg, Y. \& Rost, B. (2007). SNAP: Predict effect of non-synonymous polymorphisms on function. Nucleic Acids Research, 35(11): 3823-3835.

Cahill, D. \& Carney, J.P. (2007). Dimerization of the Rad50 protein is independent of the conserved hook domain. Mutagenesis, 22(4): 269-274.

Capriotti, E. \& Fariselli, P. (2017). PhD-SNPg: A webserver and lightweight tool for scoring single nucleotide variants. Nucleic Acids Research, 45(W1): W247-W252.

Capriotti, E., Fariselli, P. \& Casadio, R. (2005). I-Mutant2.0: Predicting stability changes upon mutation from the protein sequence or structure. Nucleic Acids Research, 33(SUPPL. 2): 306-310.

Cargill, M., Altshuler, D., Ireland, J., Sklar, P., Ardlie, K., Patil, N., Lane, C.R., Lim, E.P., Kalyanaraman, N., Nemesh, J., Ziaugra, L., Friedland, L., Rolfe, A., Warrington, J., Lipshutz, R., Daley, G.Q., Lander, E.S., Cargill, M., Sklar, P., Ireland, J., Ardlie, K., Patil, N., Lane, C.R., Lim, E.P., Kalyanaraman, N., Nemesh, J., Ziaugra, L., Friedland, L., Rolfe, A., Warrington, J., Lipshutz, R. \& Daley, G.Q. (1999). Characterization of single-nucleotide polymorphisms in coding regions of human genes. Nature, 22(July): 231-238.

Carney, J.P., Maser, R.S., Olivares, H., Davis, E.M., Le Beau, M., Yates, J.R., Hays, L., Morgan, W.F. \& Petrini, J.H. (1998a). The hMre11/hRad50 protein complex and Nijmegen breakage syndrome: linkage of double-strand break repair to the cellular DNA damage response. Cell, 93(3): 477-86.

Carney, J.P., Maser, R.S., Olivares, H., Davis, E.M., Le Beau, M., Yates, J.R., Hays, L., Morgan, W.F. \& Petrini, J.H.J. (1998b). The hMre11/hRad50 protein complex and Nijmegen breakage syndrome: Linkage of double-strand break repair to the cellular DNA damage response. Cell, 93(3): 477-486.

Chen, L., Trujillo, K.M., Van Komen, S., Roh, D.H., Krejci, L., Lewis, L.K., Resnick, M.A., Sung, P. \& Tomkinson, A.E. (2005). Effect of amino acid substitutions in the rad50 ATP binding domain on DNA double strand break repair in yeast. The Journal of Biological Chemistry, 280(4): 2620-2627.

Peer) reviewing PDF | (2019:04:36390:3:0:NEW 24 Mar 2020) 
674 Cheng, J., Randall, A. \& Baldi, P. (2006). Prediction of protein stability changes for single-site

675

676

677

678

679

680

681

682

683

684

685

686

687

688

689

690

691

692

693

694

695

696

697

698

699

700

701

702

703

704

705

706

707

708

709

710

711

712

713

mutations using support vector machines. Proteins, 62(4): 1125-1132.

Collins, F.S., Guyer, M.S. \& Charkravarti, A. (1997). Variations on a theme: cataloging human DNA sequence variation. Science, 278(5343): 1580-1.

Dagda, R.K. \& Das Banerjee, T. (2015). Role of protein kinase A in regulating mitochondrial function and neuronal development: Implications to neurodegenerative diseases. Reviews in the Neurosciences, 26(3): 359-370.

Davidson, A.L., Dassa, E., Orelle, C. \& Chen, J. (2008). Structure, function, and evolution of bacterial ATP-binding cassette systems. Microbiology and Molecular Biology Reviews, 72(2): 317-364.

Durocher, D., Taylor, I. a, Sarbassova, D., Haire, L.F., Westcott, S.L., Jackson, S.P., Smerdon, S.J. \& Yaffe, M.B. (2000). The molecular basis of FHA domain:phosphopeptide binding specificity and implications for phospho-dependent signaling mechanisms. Molecular cell, 6(5): 1169-1182.

Featherstone, C. \& Jackson, S.P. (1998). DNA repair: the Nijmegen breakage syndrome protein. Current biology, CB 8(17): R622-5.

Finn, R.D., Attwood, T.K., Babbitt, P.C., Bateman, A., Bork, P., Bridge, A.J., Chang, H.Y., Dosztanyi, Z., El-Gebali, S., Fraser, M., Gough, J., Haft, D., Holliday, G.L., Huang, H., Huang, X., Letunic, I., Lopez, R., Lu, S., Marchler-Bauer, A., Mi, H., Mistry, J., Natale, D.A., Necci, M., Nuka, G., Orengo, C.A., Park, Y., Pesseat, S., Piovesan, D., Potter, S.C., Rawlings, N.D., Redaschi, N., Richardson, L., Rivoire, C., Sangrador-Vegas, A., Sigrist, C., Sillitoe, I., Smithers, B., Squizzato, S., Sutton, G., Thanki, N., Thomas, P.D., Tosatto, S.C.E., Wu, C.H., Xenarios, I., Yeh, L.S., Young, S.Y. \& Mitchell, A.L. (2017). InterPro in 2017-beyond protein family and domain annotations. Nucleic Acids Research, 45(D1): D190-D199.

Gardner, P.P., Paterson, J.M., Ghomi, F.A., Umu, S.U.U., McGimpsey, S. \& Pawlik, A. (2017). A meta-analysis of bioinformatics software benchmarks reveals that publication-bias unduly influences software accuracy. bioRxiv, 092205.

Gatei, M., Jakob, B., Chen, P., Kijas, A.W., Becherel, O.J., Gueven, N., Birrell, G., Lee, J.H., Paull, T.T., Lerenthal, Y., Fazry, S., Taucher-Scholz, G., Kalb, R., Schindler, D., Waltes, R., Drk, T. \& Lavin, M.F. (2011). ATM protein-dependent phosphorylation of Rad50 protein Regulates DNA repair and cell cycle control. Journal of Biological Chemistry, 286(36): 31542-31556.

Halushka, M.K., Fan, J.B., Bentley, K., Hsie, L., Shen, N., Weder, A., Cooper, R., Lipshutz, R. \& Chakravarti, A. (1999). Patterns of single-nucleotide polymorphisms in candidate genes for blood-pressure homeostasis. Nature Genetics, 22(3): 239-247.

He, J., Shi, L.Z., Truong, L.N., Lu, C.S., Razavian, N., Li, Y., Negrete, A., Shiloach, J., Berns, M.W. \& Wu, X. (2012). Rad50 zinc hook is important for the Mre11 complex to bind chromosomal DNA double-stranded breaks and initiate various DNA damage responses. Journal of Biological Chemistry, 287(38): 31747-31756.

PeerJ reviewing PDF | (2019:04:36390:3:0:NEW 24 Mar 2020) 
714 Hopfner, K.-P., Craig, L., Moncalian, G., Zinkel, R. a, Usui, T., Owen, B. a L., Karcher, A., 715 Henderson, B., Bodmer, J.-L., McMurray, C.T., Carney, J.P., Petrini, J.H.J. \& Tainer, J.A. 716 (2002). The Rad50 zinc-hook is a structure joining Mre11 complexes in DNA recombination

717

718

719

720

721

722

723

724

725

726

727

728

729

730

731

732

733

734

735

736

737

738

739

740

741

742

743

744

745

746

747

748

749

750

751 and repair. Nature, 418(6897): 562-566.

de Jager, M., van Noort, J., van Gent, D.C., Dekker, C., Kanaar, R. \& Wyman, C. (2001). Human Rad50/Mre11 is a flexible complex that can tether DNA ends. Molecular cell, 8(5): 1129-35.

Jones, P., O’Mara, M. \& George, A. (2009). ABC transporters: a riddle wrapped in a mystery inside an enigma. Trends in biochemical sciences, 34(10): 520-31.

Kelley, L.A., Mezulis, S., Yates, C.M., Wass, M.N. \& Sternberg, M.J.E. (2015). The Phyre2 web portal for protein modeling, prediction and analysis. Nature Protocols, 10(6): 845-858.

Kerem, B., Rommens, J.M., Buchanan, J. a, Markiewicz, D., Cox, T.K., Chakravarti, a, Buchwald, M. \& Tsui, L.C. (1989). Identification of the cystic fibrosis gene: genetic analysis. Science, 245(4922): 1073-1080.

Koroleva, O., Makharashvili, N., Courcelle, C.T., Courcelle, J. \& Korolev, S. (2007). Structural conservation of RecF and Rad50: implications for DNA recognition and RecF function. The EMBO journal, 26(3): 867-77.

De La Rosa Metzere Bierlein \& and Scott W. Nelson. (2011). An Interaction between the Walker A and D-loop Motifs Is Critical to ATP Hydrolysis and Cooperativity in Bacteriophage. The Journal of Biological Chemistry, 286(29): 26258-26266.

Lee, J.E., Choi, J.H., Lee, J.H. \& Lee, M.G. (2005). Gene SNPs and mutations in clinical genetic testing: Haplotype-based testing and analysis. Mutation Research - Fundamental and Molecular Mechanisms of Mutagenesis, 573(1-2): 195-204.

Luo, G., Yao, M.S., Bender, C.F., Mills, M., Bladl, A.R., Bradley, A. \& Petrini, J.H. (1999). Disruption of mRad50 causes embryonic stem cell lethality, abnormal embryonic development, and sensitivity to ionizing radiation. Proceedings of the National Academy of Sciences of the United States of America, 96(13): 7376-81.

Marchal, K., De Keersmaecker, S., Monsieurs, P., van Boxel, N., Lemmens, K., Thijs, G., Vanderleyden, J. \& De Moor, B. (2004). In silico identification and experimental validation of PmrAB targets in Salmonella typhimurium by regulatory motif detection. Genome Biology, 5(2): R9

Marín-Martín, F.R., Soler-Rivas, C., Martín-Hernández, R. \& Rodriguez-Casado, A. (2014). A Comprehensive In Silico Analysis of the Functional and Structural Impact of Nonsynonymous SNPs in the ABCA1 Transporter Gene. Cholesterol, 2014: 1-19.

Matsuura, S., Tauchi, H., Nakamura, A., Kondo, N., Sakamoto, S., Endo, S., Smeets, D., Solder, B., Belohradsky, B.H., Der Kaloustian, V.M., Oshimura, M., Isomura, M., Nakamura, Y. \& Komatsu, K. (1998). Positional cloning of the gene for Nijmegen breakage syndrome. Nature genetics, 19(2): 179-181. 
752

753

754

755

756

757

758

759

760

761

762

763

764

765

766

767

768

769

770

771

772

773

774

775

776

777

778

779

780

781

782

783

784

785

786

787

788

789

790

791

Moncalian, G., Lengsfeld, B., Bhaskara, V., Hopfner, K.P., Karcher, A., Alden, E., Tainer, J.A. \& Paull, T.T. (2004). The Rad50 Signature Motif: Essential to ATP Binding and Biological Function. Journal of Molecular Biology, 335(4): 937-951.

Pejaver, V., Urresti, J., Lugo-Martinez, J., Pagel, K.A., Lin, G.N., Nam, H.-J., Mort, M., Cooper, D.N., Sebat, J., Iakoucheva, L.M., Mooney, S.D. \& Radivojac, P. (2017). MutPred2: inferring the molecular and phenotypic impact of amino acid variants. bioRxiv, :134981.

Pettersen, E.F., Goddard, T.D., Huang, C.C., Couch, G.S., Greenblatt, D.M., Meng, E.C. \& Ferrin, T.E. (2004). UCSF Chimera--a visualization system for exploratory research and analysis. Journal Comput Chemistry, 25(13): 1605-1612.

Piro, R.M. \& Di Cunto, F. (2012). Computational approaches to disease-gene prediction: Rationale, classification and successes. FEBS Journal,279(5): 678-696.

Ptacek, J. \& Snyder, M. (2006). Charging it up: global analysis of protein phosphorylation.

Ramensky, V. 2002. Human non-synonymous SNPs: server and survey. Nucleic Acids Research, 30(17): 3894-3900.

Risch, N. \& Merikangas, K. (1996). The future of genetic studies of complex human diseases. Science, 273(5281): 1516-1517.

Rojowska, A., Lammens, K., Seifert, F.U., Direnberger, C. \& Feldmann, H. (2014). Structure of the Rad 50 DNA double-strand break repair protein in complex with DNA. The EMBO journal, 33(23): 2847-2859.

Roset, R., Inagaki, A., Hohl, M., Brenet, F., Lafrance-Vanasse, J., Lange, J., Scandura, J.M., Tainer, J.A., Keeney, S. \& Petrini, J.H.J. (2014). The Rad50 hook domain regulates DNA damage signaling and tumorigenesis. Genes and Development, 28(5): 451-462.

Schymkowitz, J., Borg, J., Stricher, F., Nys, R., Rousseau, F. \& Serrano, L. (2005). The FoldX web server: An online force field. Nucleic Acids Research, 33(SUPPL. 2).

Shaikho, E.M., Farrell, J.J., Alsultan, A., Qutub, H., Al-Ali, A.K., Figueiredo, M.S., Chui, D.H.K., Farrer, L.A., Murphy, G.J., Mostoslavsky, G., Sebastiani, P. \& Steinberg, M.H. (2017). A phased SNP-based classification of sickle cell anemia HBB haplotypes. BMC Genomics, 18(1): 608.

Shiloh, Y. \& Ziv, Y. (2013). The ATM protein kinase: Regulating the cellular response to genotoxic stress, and more. Nature reviews. Molecular cell biology, 14(4): 197-210.

Sievers, F. \& Higgins, D.G. (2018). Clustal Omega for making accurate alignments of many protein sequences. Protein Science, 27(1):135-145.

Sim, N.-L., Kumar, P., Hu, J., Henikoff, S., Schneider, G. \& Ng, P.C. (2012). SIFT web server: predicting effects of amino acid substitutions on proteins. Nucleic Acids Research, 40(W1): W452-W457.

Stone, E.A. \& Sidow, A. (2005). Physicochemical constraint violation by missense substitutions mediates impairment of protein function and disease severity. Genome Research, 15(7): 978-986.

Symington, L.S. (2002). Role of RAD52 epistasis group genes in homologous recombination and double-strand break repair. Microbiology and molecular biology reviews, 66(4): 630-70.

Peer) reviewing PDF | (2019:04:36390:3:0:NEW 24 Mar 2020) 
792

793

794

795

796

797

798

799

800

801

802

803

804

805

806

807

808

809

810

811

812

813

Tchernitchko, D., Goossens, M. \& Wajcman, H. (2004). In silico prediction of the deleterious effect of a mutation: Proceed with caution in clinical genetics. Clinical Chemistry, 50(11): 1974-1978.

Thompson, J.D., Gibson, T.J. \& Higgins, D.G. (2002). Multiple Sequence Alignment Using ClustalW and ClustalX. Current Protocols in Bioinformatics, 0(1): 2.3.1-2.3.22.

Traeger, J., Wood, W.G., Clegg, J.B., Weatherall, D.J. \& Wasi, P. (1980). Defective synthesis of $\mathrm{HbE}$ is due to reduced levels of $\beta E$ mRNA. Nature 288(5790): 497-499.

Tranchevent, L.C., Capdevila, F.B., Nitsch, D., de Moor, B., de Causmaecker, P. \& Moreau, Y. (2011). A guide to web tools to prioritize candidate genes. Briefings in Bioinformatics, 12(1): 22-32.

Varon, R., Vissinga, C., Platzer, M., Cerosaletti, K.M., Chrzanowska, K.H., Saar, K., Beckmann, G., Seemanová, E., Cooper, P.R., Nowak, N.J., Stumm, M., Weemaes, C.M., Gatti, R. a, Wilson, R.K., Digweed, M., Rosenthal, a, Sperling, K., Concannon, P. \& Reis, a. (1998). Nibrin, a novel DNA double-strand break repair protein, is mutated in Nijmegen breakage syndrome. Cell, 93(3): 467-476.

Waltes, R., Kalb, R., Gatei, M., Kijas, A.W., Stumm, M., Sobeck, A., Wieland, B., Varon, R., Lerenthal, Y., Lavin, M.F., Schindler, D. \& Dörk, T. (2009). Human RAD50 Deficiency in a Nijmegen Breakage Syndrome-like Disorder. American Journal of Human Genetics, 84(5): 605-616.

Wan, J., Kang, S., Tang, C., Yan, J., Ren, Y., Liu, J., Gao, X., Banerjee, A., Ellis, L.B.M. \& Li, T. (2008). Meta-prediction of phosphorylation sites with weighted voting and restricted grid search parameter selection. Nucleic Acids Research, 36(4): 22.

Peer) reviewing PDF | (2019:04:36390:3:0:NEW 24 Mar 2020) 


\section{Figure 1}

Domain analysis and multiple sequence alignment.

Domain analysis using InterPro shows that Rad50 contains P-loop containing nucleoside triphosphate hydrolase domain belongs to the ATP Binding Cassette (ABC) protein superfamily (pink box) as well as a special domain called zinc hook, which so far does not overlap with any homologous superfamilies (blue box) (a). ABC protein consists of six conserved motifs; i.e. Walker A (WA), Q-loop (QL), signature motif (SM), Walker B (WB), Dloop (DL), and $\mathrm{H}$-loop $(\mathrm{HL})$ which make up the nucleotide binding domain. Zinc hook domain contains a conserved CxxC motif located at the residue number 681-684 (a). All deleterious residues identified from the literature were highlighted based on human equivalent mutation (Supplementary Table S1) and those occurring only in the conserved regions are shown in (b). Multiple sequence alignment (MSA) analysis of Rad50 sequences dataset (human, $D$. rerio (zebrafish), M. musculus (mouse), $R$. norvegicus (rat), P. troglodytes (chimpanzee), $O$. cuniculus (rabbit), D. melanogaster (fruit fly), S. cerevisiae (yeast) and S. pombe (yeast)) showed conserved residues in specific motifs (b). An "*" (asterisk) indicates position which has a single, fully conserved residue. A ":" (colon) indicates conservation between groups of strongly similar properties - scoring > 0.5 in the Gonnet PAM250 matrix. A "." (period) indicates conservation between groups of weakly similar properties - scoring $\leq 0.5$ in the Gonnet PAM250 matrix. 


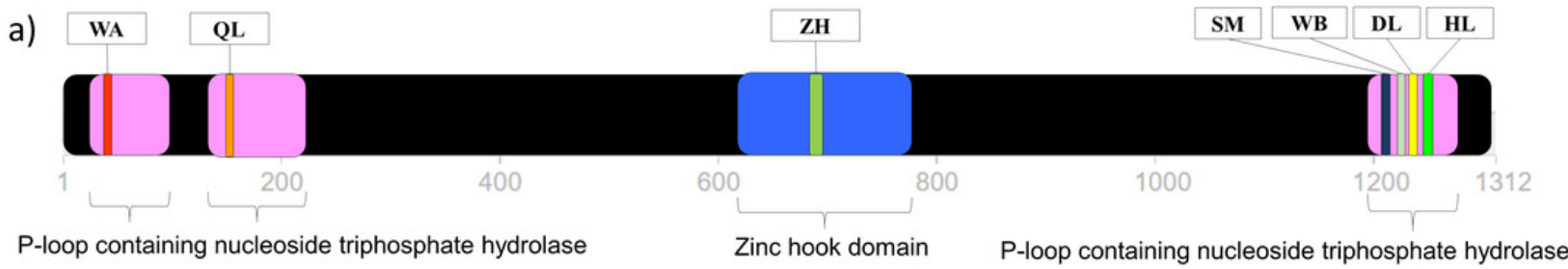

b)

H. sapiens

D. rerio

M.musculus

$R$. norvegicus

P.troglodytes

O. cuniculus

S. cerevisiae

S. pombe

D.melanogaster

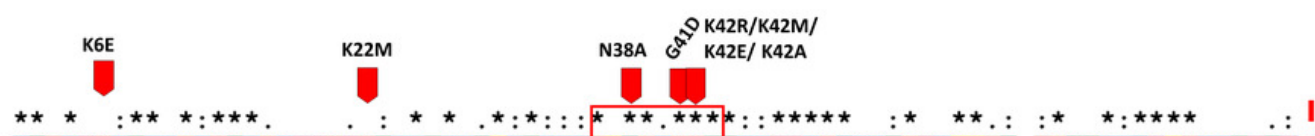
MSRIEKMSILGVRSFGIEDKDKQIITFFSPLTILVGPNGAGKTIIIECLKYICTGDFPPGT-KGNTFVHDPKVAQETD | MSKIEKMSILGVRSFGVEDKDKQVISFFSPLTVLV GPNGAGKTIIIECLKYITSGDFPPGS-KGNTFVHDPKDAHETD MSRIEKMSILGVRSFGIEDKDKOIISFF SP LTILV GPNGAGKTIIIECLKYICT GDFPPGT-KGNTFVHDPKVAQETD MSRIEKMSILGVRSFGIEDKDKOIISFF SPLTILV GPNGAGKTIIIECLKYICT GDFPPGT-KGNTFVHDPKVAQETD I MSRIEKMSILGVRSFGIEDKDKQIITFF SPLTILV GPNGAGKTIIIECLKYICT GDFPPGT-KGNTFVHDPKVAQETD | MSRIEKMSILGVRSFGIEDKDKQIITFFSPLTILV GPNGAGKTIIIECLKYICT GDFPPGT-KGNTFVHDPKVAQETD MSAIYKLSIQGIRSFDSN--DRETIEFGKPLTLIVGMNGSGKTIIIECLKYATTGDLPPNS-KGGVFIHDPKITGEKD MSCIDRMSIMGIRSFDNR--SRESIQFFSP LTLIVGQNGSGKTIIIECLKYATTGILPPNT-KGGAFIHDPKICGEKE I MSSIESLSIQGIRSFGTYADDLQSIKFSSPVTLIL GENGCGKTIVVECLKYALT GECPPGSDRGKSFVHDPKIFGLNE I

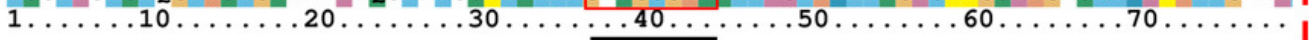
Walker A

\begin{tabular}{lll} 
& \multicolumn{1}{c}{ R83I } & \\
& &
\end{tabular}

H. sapiens

D. rerio

M.musculus

R. norvegicus

P.troglodytes

O. cuniculus

S. cerevisiae

S. pombe

D. melanogaster

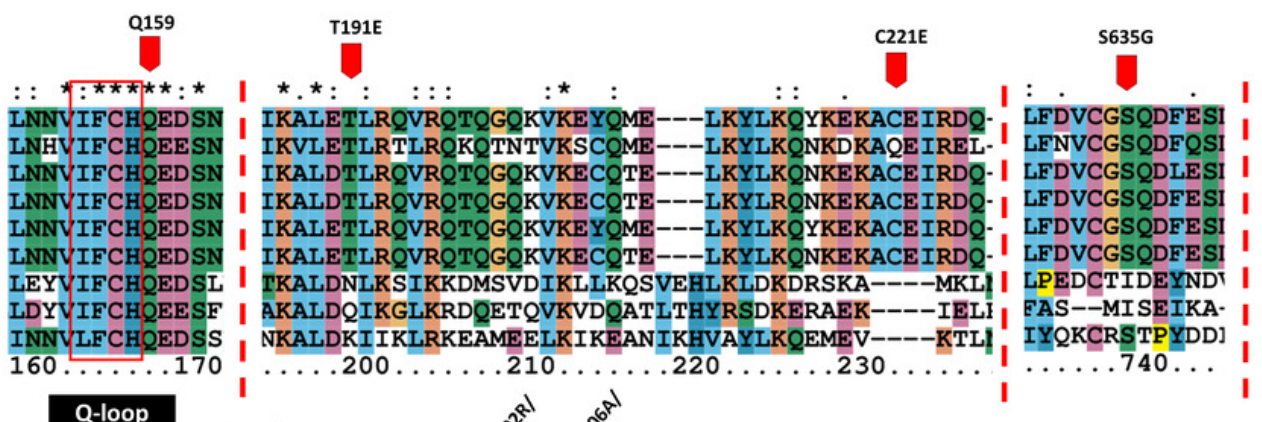

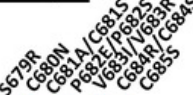

.

H. sapiens

D. rerio

M.musculus

$R$. norvegicus

P.troglodytes

O. cuniculus

S.cerevisiae

S. pombe

D.melanogaster
LTDENQSCCPVCQRVFQT LTEEGDPCCPVCQRVFPS] LTDENQSCCPVCQRVFQT]

LTDENQSCCPVCQRVFQT]

LTDENQSCCPVCQRVFQT]
LTDENOSCCPVCORVFOT]

LTDENQSCCPVCQRVFQT]
AER--DSCCYLCSRKFEN]

CVD--QHACQLCQRSLDK

MDE--EPS CPLCHHNMTSI . .780.

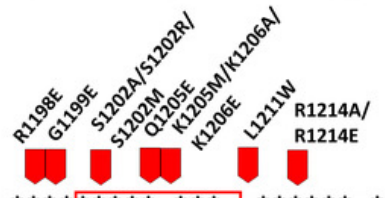

E1232Q D1238N/ DMRGRCSAGQKVLASIIIIRLALAETFCLNCGI IALDEP TTNLDRENIESLAHALVEII DMRGRCSAGQKVLASLI IRLALAETFCLNCG ILALDEP TTNLDRENIESIAHALVE I I DMRGRCSAGOKVLASLIIRLALAETFCLNCGILALDEPTTNLDRENIESLAHALVE II DMRGRCSAGOKVLASL I IRLALAETFCLNCGI LALDEPTTNLDRENIESLAHALVE I I DMRGRCSAGQKVLASL I IRLALAETFCLNCG I IALDEPTTNLDREN IESLAHALVE I I DMRGRCSAGQKVLAS L I IRLALAETFCLNCGI LALDEPTTNLDRENIESLAHALVE I I DMRGRCSAGOKVL.AS I IRL.ALSETFGANCGVIAL.DEPTTNLDEENIEST.AKSLHNI I DMRGRCSAGQKVLACI I IRLALAECLGVNCG I LALDEPTTNLDEENICSLAKNLSRIV] EMRGRCSAGQRVLASLI IRLALAETFS SNCGVLALDEPTTNLDRANINSLCEALNCIV] BMRGRCSAGQRVLASLIIRLALAETFSSI 


\section{Figure 2}

3D structure of Rad50.

3D structure of Rad50. A 3D structure of Rad50 human modelled using fold recognition technique Phyre2 using structure from Chaetomium thermophilum as a template (PDB ID: 5DAC). N-terminal of 276 residues (2-278) and C-terminal of 155 residues (1153-1306) are colored as blue and green; respectively (a). All six motifs identified are marked and represented by ball and stick representation with different colours (orange for Q-loop, blue for Walker B, purple for signature motif, yellow for D-loop, grey for Walker A and green from $\mathrm{H}$-loop) (a). All mutated residues identified were marked and labelled in the 3D structure (b). Zinc hook structure of 181 residues (residue 585-766) that has been determined (PDB ID: 5GOX) and its deleterious residues also marked in the structure $(c, d)$. All figures were generated using UCSF Chimera (Pettersen et al., 2004) 


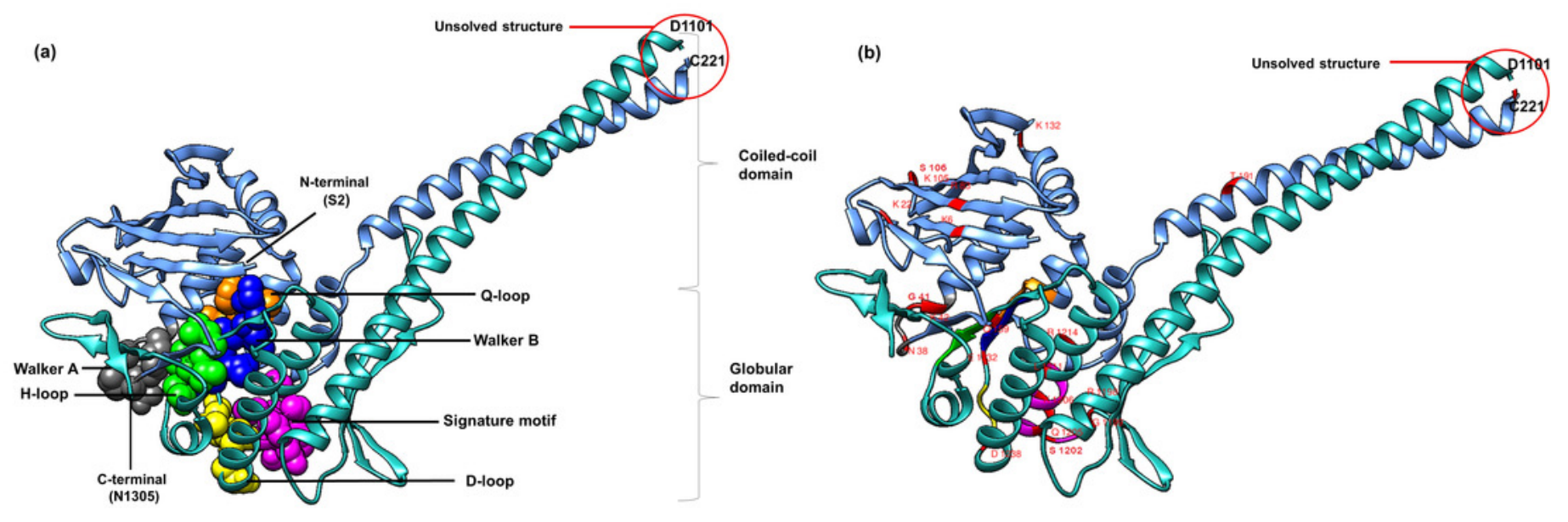

(c)

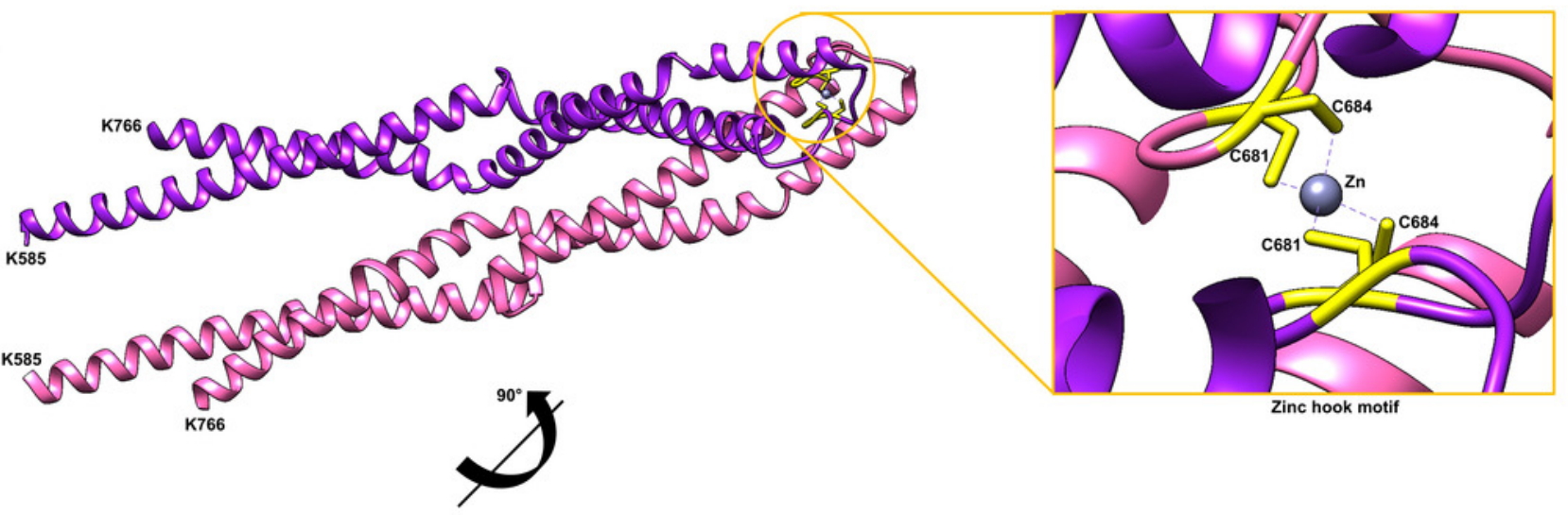

(d)

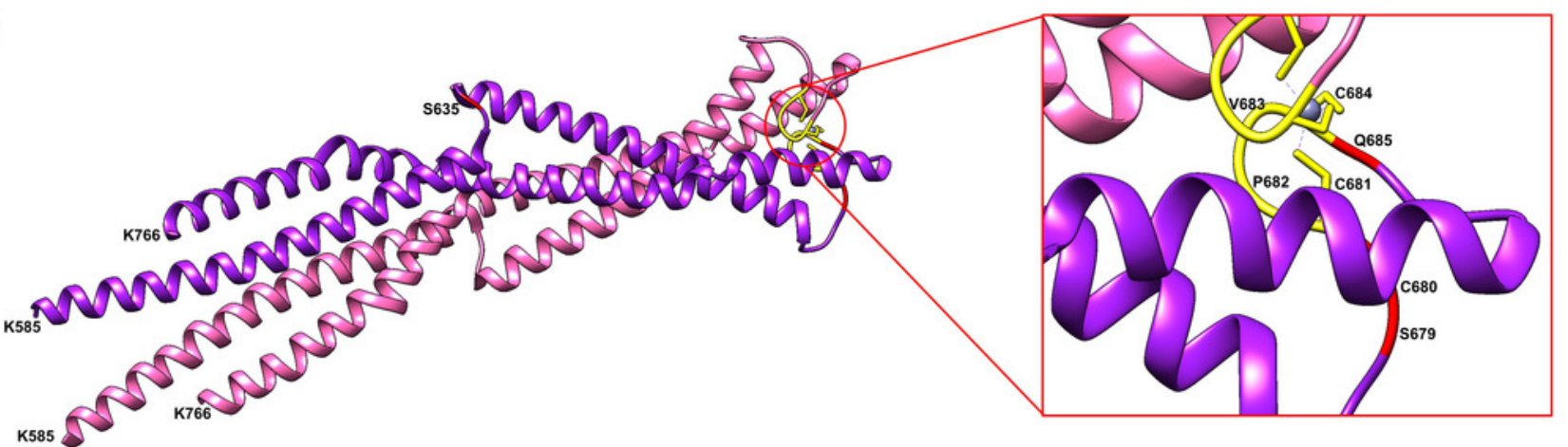




\section{Table $\mathbf{1}$ (on next page)}

Summary of the most damaging effects of Rad50 mutations obtained from previous in vitro and in vivo experiments.

Abbreviations: HR (homologous recombination), NHEJ (non-homologous end joining repair), CFTR (cystic fibrosis transmembrane conductance regulator), ATP (adenosine tri-phosphate), ATM (ataxia-telangiectasia mutated), ATR (ATM-and Rad3-Related). Refer to Table S2 for the description of all mutations. 


\begin{tabular}{|c|c|c|c|c|}
\hline Motif/domain & Mutations & Organism & Effects & Ref. \\
\hline Walker A & $\mathrm{K} 40 \mathrm{~A} / \mathrm{R} / \mathrm{E}$ & S. cerevisiae & $\begin{array}{l}\text { - HR and NHEJ defects and lower ATPase } \\
\text { activity }\end{array}$ & $\begin{array}{l}\text { (Chen et al., } \\
2005)\end{array}$ \\
\hline $\begin{array}{l}\text { Walker A } \\
\text { D-loop }\end{array}$ & $\begin{array}{l}\mathrm{N} 38 \mathrm{~A}, \\
\mathrm{D} 512 \mathrm{~N} / \mathrm{A}\end{array}$ & $\begin{array}{l}\mathrm{T} 4 \\
\text { bacteriophage }\end{array}$ & $\begin{array}{l}\text { - Naturally occurring mutation of CFTR } \\
\text { protein } \\
\text { - Reduce in ATP activity }\end{array}$ & $\begin{array}{l}\text { (De La Rosa } \\
\text { Metzere Bierlein } \\
\text { and and Scott W. } \\
\text { Nelson, 2011) }\end{array}$ \\
\hline $\begin{array}{l}\text { ATP binding } \\
\text { domain and } \\
\text { Walker A }\end{array}$ & $\begin{array}{l}\text { G39D, K40E } \\
\text { K81I, R20M }\end{array}$ & S. cerevisiae & - Total defect in formation of viable spore & $\begin{array}{l}\text { (Alani, Padmore } \\
\text { and Kleckner, } \\
\text { 1990) }\end{array}$ \\
\hline $\begin{array}{l}\text { ATP binding } \\
\text { domain }\end{array}$ & $\begin{array}{l}\text { K6E, K22M, } \\
\text { R83I }\end{array}$ & M. musculus & $\begin{array}{l}\text { - Embryonic lethality, growth defect, cancer } \\
\text { predisposition, hematopoietic and } \\
\text { spermatogenic depletion }\end{array}$ & $\begin{array}{l}\text { (Bender } \text { et al., } \\
\text { 2002) }\end{array}$ \\
\hline Walker A & K39R, K42M & D. radiodurans & - Prevented ATP binding and hydrolysis & $\begin{array}{l}\text { (Koroleva et al., } \\
\text { 2007) }\end{array}$ \\
\hline $\begin{array}{l}\text { ATPase binding } \\
\text { domain, } \\
\text { Walker B } \\
\text { and } \\
\text { Signature motif }\end{array}$ & $\begin{array}{l}\text { E798Q, } \\
\text { S768R, } \\
\text { K103E, } \\
\text { K104E, } \\
\text { R131E, } \\
\text { R1202E, } \\
\text { S1205R, } \\
\text { E1235Q }\end{array}$ & S. cerevisiae & $\begin{array}{l}\text { In vitro: Thermotoga maritima } \\
\text { - K175E, K182E, K115E Reduced DNA } \\
\text { binding } \\
\text { - R94E and K95E: Important for DNA } \\
\text { binding } \\
\text { - R765E: Diminished DNA binding } \\
\text { - E798Q: Low affinity to DNA } \\
\text { - S768R: Reduced DNA binding } \\
\text { In vivo: Saccharomyces cerevisiae } \\
\text { - S1205R and E1235Q double mutation: } \\
\text { Unable to rescue the impaired DNA damage } \\
\text { response } \\
\text { - K103E, K104E and R131E: Strongly } \\
\text { affected DNA binding and moderate } \\
\text { reduction in telomere length } \\
\text { - K103E and R131R (double mutation) and } \\
\text { R1201E: Significantly reduced telomere } \\
\text { length } \\
\text { - S1205R: Significantly reduced telomere } \\
\text { length }\end{array}$ & $\begin{array}{l}\text { (Rojowska et al., } \\
\text { 2014b) }\end{array}$ \\
\hline \multirow[t]{4}{*}{ Zinc hook } & $\begin{array}{l}\text { S679R, P682E } \\
\text { V683R }\end{array}$ & M. musculus & $\begin{array}{l}\text { - Lethality in mice. Hydrocephalus, defects in } \\
\text { primitive hematopoietic and gametogenic } \\
\text { cells }\end{array}$ & $\begin{array}{l}\text { (Roset et al., } \\
\text { 2014) }\end{array}$ \\
\hline & $\begin{array}{l}\text { C684N, C685A } \\
\text { P686A } \\
\text { V6871 } \\
\text { C688R } \\
\text { Q689S }\end{array}$ & S. cerevisiae & $\begin{array}{l}\text { - Defective to be recruited to chromosomal } \\
\text { double strand break } \\
\text { - Phenotype as severe as Rad50 null mutant } \\
\text { - Defective in ATM activation, HR, sensitive } \\
\text { to irradiation and ATR activation }\end{array}$ & (He et al., 2012) \\
\hline & C288S, C291S & $\begin{array}{l}\text { T4 } \\
\text { bacteriophage }\end{array}$ & - Double mutation is lethal & $\begin{array}{l}\text { (Barfoot et al., } \\
\text { 2015) }\end{array}$ \\
\hline & S635G & H. sapiens & $\begin{array}{l}\text { - Chromosomal instability } \\
\text { - Defective ATM-dependent signalling }\end{array}$ & $\begin{array}{l}\text { (Gatei } \text { et al., } \\
\text { 2011) }\end{array}$ \\
\hline
\end{tabular}




\begin{tabular}{|c|c|c|c|c|}
\hline & $\begin{array}{l}\text { S685R } \\
\text { Y688E } \\
\text { L689R }\end{array}$ & S. cerevisiae & $\begin{array}{l}\text { - S685R and Y688E double mutation: } \\
\text { Sporulation efficiency and viability were } \\
\text { severely impaired followed by L689R } \\
\text { - Rad50-Mre11 interaction was strongly } \\
\text { impaired, partial suppression of telomere } \\
\text { and meiotic defects }\end{array}$ & $\begin{array}{l}\text { (Hohl et al., } \\
\text { 2015) }\end{array}$ \\
\hline \multirow[t]{4}{*}{$\begin{array}{l}\text { Rad50 Signature } \\
\text { motif }\end{array}$} & $\begin{array}{l}\text { R805E } \\
\text { L802W }\end{array}$ & P. furiosus & $\begin{array}{l}\text { L802W: Decrease dimerization in ATP, } \\
\text { hydrolysis and cleavage site } \\
\text { R805E: Poorly grown in camptothecin; } \\
\text { inability to repair endogenous DNA damage } \\
\text { by HR and showed defect in resection in } \\
\text { HO endonuclease induced }\end{array}$ & $\begin{array}{l}\text { (Deshpande et } \\
\text { al., 2014) }\end{array}$ \\
\hline & $\begin{array}{l}\text { K1187A } \\
\text { K1187E } \\
\text { R1195A } \\
\text { R1195E }\end{array}$ & S. pombe & $\begin{array}{l}\text { - K1187A: Sensitive in higher dose of } \\
\text { clastogens } \\
\text { K1187E, R1195A and R1195E: } \\
\text { Significantly sensitive to clastogen agents } \\
\text { and were deleterious as Rad50 null } \\
\text { mutation }\end{array}$ & $\begin{array}{l}\text { (Williams et al., } \\
\text { 2011) }\end{array}$ \\
\hline & $\begin{array}{l}\text { S471A/R/M, } \\
\text { E474Q,K475M }\end{array}$ & $\begin{array}{l}\text { T4 } \\
\text { bacteriophage }\end{array}$ & $\begin{array}{l}\text { - S471A/R.M, E474Q and K475M: Residues } \\
\text { involved in the allosteric transmission } \\
\text { between DNA and ATP binding sites }\end{array}$ & $\begin{array}{l}\text { (Herdendorf and } \\
\text { Nelson, 2011) }\end{array}$ \\
\hline & $\begin{array}{l}\text { S1205R } \\
\text { S793R } \\
\text { S1202R }\end{array}$ & $\begin{array}{l}\text { S. cerevisiae } \\
\text { P. furiosus } \\
\text { H. sapiens }\end{array}$ & $\begin{array}{l}\text { - S1202R: Reduced adenylate kinase } \\
\text { - S793R: Deficient in ATP-dependent dimer } \\
\text { formation and ATP binding } \\
\text { - S1202R and S1205R: Low level of } \\
\text { adenylate kinase } \\
\text { - S1205R: Telomere shortening, not support } \\
\text { spore viability }\end{array}$ & $\begin{array}{l}\text { (Bhaskara et al., } \\
\text { 2007) }\end{array}$ \\
\hline $\begin{array}{l}\text { Signature motif } \\
\text { and Q loop }\end{array}$ & S1205R & S. cerevisiae & $\begin{array}{l}\text { - S793R: Analogs to the mutation in CFTR } \\
\text { (S549R) gene that results cystic fibrosis } \\
\text { - S793R: Prevented ATP binding } \\
\text { - S1205R S. cerevisiae: Failed to complement } \\
\text { Rad50 deletion strain in DNA repair assay } \\
\text { - S783R and Q140H: Halted ATP-dependent } \\
\text { activities }\end{array}$ & $\begin{array}{l}\text { (Moncalian, } \\
\text { Lengsfeld, } \\
\text { Bhaskara, } \\
\text { Hopfner, } \\
\text { Karcher, Alden, } \\
\text { J. A. Tainer, et } \\
\text { al., 2004) }\end{array}$ \\
\hline ATPase domain & $\begin{array}{l}\text { R1093(stop) } \\
\text { c.3939A/T }\end{array}$ & H. sapiens & $\begin{array}{l}\text { - Nijmegen breakage syndrome like disorder } \\
\text { (NBSLD) }\end{array}$ & $\begin{array}{l}\text { (Waltes et al., } \\
\text { 2009) }\end{array}$ \\
\hline
\end{tabular}




\section{Table 2 (on next page)}

In silico analysis of 42 deleterious mutations in Rad50.

Different tools were used to analyse all mutations as abbreviated in the table. PS

(PredictSNP), MP (MAPP), PhS (PhD-SNP), PP1 (Poly-Phen1), PP2 (Poly-Phen2), SF (SIFT), SN

(SNAP), IM (I-Mutant), MPr (MuPro), Pr (probability), AG (protein aggregation) and AM (Amyloid aggregation). Please refer to Materials and Methods for detailed descriptions of these tools. Note that all mutations listed above are based on the equivalent mutations in human. 
1

\begin{tabular}{|c|c|c|c|c|c|c|c|c|c|c|c|c|c|c|c|c|}
\hline \multirow[b]{2}{*}{ Motif } & \multirow[b]{2}{*}{$\begin{array}{l}\text { Mutation } \\
\text { [source] }\end{array}$} & \multicolumn{7}{|c|}{$\begin{array}{l}\text { Amino acid Impact (PredictSNP) } \\
\text { (Neutral/Deleterious) }\end{array}$} & \multicolumn{4}{|c|}{ Molecular mechanisms (MutPred2) } & \multicolumn{2}{|c|}{$\begin{array}{l}\text { Structural } \\
\text { phenotyping } \\
\text { (SNPeffect) }\end{array}$} & \multicolumn{2}{|c|}{$\begin{array}{l}\begin{array}{l}\text { Protein stability } \\
\text { (Imutant/ } \\
\text { MuPro) }\end{array} \\
\text { (umo }\end{array}$} \\
\hline & & PS & MP & Ph-S & PP-1 & PP-2 & $\mathbf{S F}$ & SP & Affected molecular mechanisms & Pr & P-value & Affected functional sites & AG & AM & IM & MPr \\
\hline \multirow[t]{6}{*}{ Walker A } & $\begin{array}{l}\text { N38A (De La } \\
\text { Rosa Metzere } \\
\text { Bierlein and } \\
\text { and Scott W. } \\
\text { Nelson, 2011) }\end{array}$ & $\mathrm{D}$ & $\mathrm{D}$ & $\mathrm{D}$ & $\mathrm{D}$ & $\mathrm{D}$ & $\mathrm{D}$ & $\mathrm{D}$ & $\begin{array}{l}\text { Loss of catalytic site at N38 } \\
\text { Loss of relative solvent accessibility } \\
\text { Altered ordered interface } \\
\text { Loss of allosteric site at N38 } \\
\text { Altered DNA binding } \\
\text { Altered metal binding } \\
\text { Gain of methylation at K42 }\end{array}$ & $\begin{array}{l}0.53 \\
0.34 \\
0.33 \\
0.31 \\
0.25 \\
0.23 \\
0.17\end{array}$ & $\begin{array}{l}8.8 \mathrm{e}-05 \\
3.4 \mathrm{e}-03 \\
9.9 \mathrm{e}-03 \\
3.0 \mathrm{e}-03 \\
6.7 \mathrm{e}-03 \\
0.02 \\
8.4 \mathrm{e}-03 \\
\end{array}$ & - ATP/GTP-binding site motif A (P-loop) & No & No & $\downarrow$ & $\downarrow$ \\
\hline & $\begin{array}{l}\text { G41D (Alani, } \\
\text { Padmore and } \\
\text { Kleckner, } \\
\text { 1990) }\end{array}$ & $\mathrm{D}$ & $\mathrm{D}$ & $\mathrm{D}$ & $\mathrm{D}$ & $\mathrm{D}$ & $\mathrm{D}$ & $\mathrm{D}$ & $\begin{array}{l}\text { Altered metal binding } \\
\text { Gain of allosteric site at G41 } \\
\text { Altered ordered interface } \\
\text { Gain of relative solvent accessibility } \\
\text { Gain of helix } \\
\text { Loss of strand } \\
\text { Altered DNA binding } \\
\text { Loss of catalytic site at N38 } \\
\text { Loss of methylation at K42 }\end{array}$ & $\begin{array}{l}0.40 \\
0.33 \\
0.30 \\
0.29 \\
0.29 \\
0.28 \\
0.28 \\
0.27 \\
0.17\end{array}$ & $\begin{array}{l}1.7 \mathrm{e}-04 \\
6.4 \mathrm{e}-04 \\
0.02 \\
0.01 \\
0.01 \\
9.7 \mathrm{e}-03 \\
4.3 \mathrm{e}-03 \\
3.7 \mathrm{e}-03 \\
0.01 \\
\end{array}$ & $\begin{array}{l}\text { - FHA phosphopeptide ligands } \\
\text { - CK2 Phosphorylation site } \\
\text { - N-myristoylation site } \\
\text { - ATP/GTP-binding site motif A (P-loop) }\end{array}$ & No & No & $\downarrow$ & $\downarrow$ \\
\hline & $\begin{array}{l}\text { K42R (Chen et } \\
\text { al., 2005) } \\
\text { (Koroleva et } \\
\text { al., 2007) }\end{array}$ & $\mathrm{D}$ & $\mathrm{D}$ & $\mathrm{D}$ & $\mathrm{D}$ & $\mathrm{D}$ & $\mathrm{D}$ & $\mathrm{D}$ & $\begin{array}{l}\text { Loss of relative solvent accessibility } \\
\text { Altered DNA binding } \\
\text { Loss of allosteric site at T44 } \\
\text { Loss of catalytic site at N38 } \\
\text { Altered metal binding } \\
\text { Loss of methylation at K42 }\end{array}$ & $\begin{array}{l}0.30 \\
0.28 \\
0.28 \\
0.27 \\
0.25 \\
0.20 \\
\end{array}$ & $\begin{array}{l}9.6 \mathrm{e}-03 \\
3.2 \mathrm{e}-03 \\
7.3 \mathrm{e}-03 \\
3.4 \mathrm{e}-03 \\
0.01 \\
6.9 \mathrm{e}-03 \\
\end{array}$ & $\begin{array}{l}\text { - FHA phosphopeptide ligands } \\
\text { - PKA phosphorylation site } \\
\text { - CK2 phosphorylation site } \\
\text { - N-myristoylation site } \\
\text { - ATP/GTP-binding site motif A (P-loop) }\end{array}$ & No & No & $\downarrow$ & $\downarrow$ \\
\hline & $\begin{array}{l}\text { K42M } \\
\text { (Koroleva et } \\
\text { al., 2007) }\end{array}$ & $\mathrm{D}$ & $\mathrm{D}$ & $\mathrm{D}$ & $\mathrm{D}$ & $\mathrm{D}$ & $\mathrm{D}$ & $\mathrm{D}$ & $\begin{array}{l}\text { Altered DNA binding } \\
\text { Loss of allosteric site at K42 } \\
\text { Loss of relative solvent accessibility } \\
\text { Altered ordered interface } \\
\text { Gain of catalytic site at T43 } \\
\text { Altered metal binding } \\
\text { Loss of methylation at K42 }\end{array}$ & $\begin{array}{l}0.37 \\
0.36 \\
0.34 \\
0.32 \\
0.29 \\
0.28 \\
0.20\end{array}$ & $\begin{array}{l}7.1 \mathrm{e}-04 \\
1.1 \mathrm{e}-03 \\
3.1 \mathrm{e}-03 \\
0.01 \\
1.6 \mathrm{e}-03 \\
5.8 \mathrm{e}-03 \\
6.8 \mathrm{e}-03 \\
\end{array}$ & $\begin{array}{l}\text { - FHA phosphopeptide ligands } \\
\text { - CK2 phosphorylation site } \\
\text { - N-myristoylation site } \\
\text { - ATP/GTP-binding site motif A (P-loop) }\end{array}$ & No & No & $\uparrow$ & $\uparrow$ \\
\hline & $\begin{array}{l}\text { K42E (Alani, } \\
\text { Padmore and } \\
\text { Kleckner, } \\
\text { 1990) (Chen et } \\
\text { al., 2005) }\end{array}$ & $\mathrm{D}$ & $\mathrm{D}$ & $\mathrm{D}$ & $\mathrm{D}$ & $\mathrm{D}$ & $\mathrm{D}$ & $\mathrm{D}$ & $\begin{array}{l}\text { Altered metal binding } \\
\text { Gain of catalytic site at T43 } \\
\text { Altered DNA binding } \\
\text { Loss of allosteric site at K42 } \\
\text { Altered ordered interface } \\
\text { Loss of relative solvent accessibility } \\
\text { Gain of strand } \\
\text { Loss of methylation at K42 }\end{array}$ & $\begin{array}{l}0.44 \\
0.33 \\
0.33 \\
0.30 \\
0.29 \\
0.29 \\
0.27 \\
0.20\end{array}$ & $\begin{array}{l}4.5 \mathrm{e}-04 \\
6.4 \mathrm{e}-04 \\
1.3 \mathrm{e}-03 \\
4.3 \mathrm{e}-03 \\
0.02 \\
0.01 \\
0.03 \\
6.8 \mathrm{e}-03\end{array}$ & $\begin{array}{l}\text { - FHA phosphopeptide ligands } \\
\text { - CK2 phosphorylation site } \\
\text { - Polo-like kinase phosphorylation sit } \\
\text { - N-myristoylation site } \\
\text { - ATP/GTP-binding site motif A (P-loop) }\end{array}$ & No & No & $\downarrow$ & $\downarrow$ \\
\hline & $\begin{array}{l}\text { K42A (Chen et } \\
\text { al., 2005) }\end{array}$ & $\mathrm{D}$ & $\mathrm{D}$ & $\mathrm{D}$ & $\mathrm{D}$ & $\mathrm{D}$ & $\mathrm{D}$ & $\mathrm{D}$ & $\begin{array}{l}\text { Loss of allosteric site at K42 } \\
\text { Loss of relative solvent accessibility } \\
\text { Altered DNA binding } \\
\text { Altered ordered interface } \\
\text { Gain of catalytic site at T43 } \\
\text { Altered metal binding } \\
\text { Loss of methylation at K42 }\end{array}$ & $\begin{array}{l}0.53 \\
0.37 \\
0.37 \\
0.36 \\
0.32 \\
0.31 \\
0.20\end{array}$ & $\begin{array}{l}5.4 \mathrm{e}-05 \\
1.6 \mathrm{e}-03 \\
6.0 \mathrm{e}-04 \\
4.2 \mathrm{e}-03 \\
8.7 \mathrm{e}-04 \\
0.01 \\
6.8 \mathrm{e}-03 \\
\end{array}$ & $\begin{array}{l}\text { FHA phosphopeptide ligands } \\
\text { - CK2 phosphorylation site } \\
\text { - N-myristoylation site } \\
\text { - ATP/GTP-binding site motif A (P-loop) }\end{array}$ & No & No & $\downarrow$ & $\downarrow$ \\
\hline Q-loop & $\begin{array}{l}\text { Q159H(Moncal } \\
\text { ian, Lengsfeld, } \\
\text { Bhaskara, } \\
\text { Hopfner, } \\
\text { Karcher, Alden, } \\
\text { J. A. Tainer, } e t\end{array}$ & $\mathrm{D}$ & $\mathrm{D}$ & $\mathrm{D}$ & $\mathrm{D}$ & $\mathrm{D}$ & $\mathrm{D}$ & $\mathrm{D}$ & No effect & - & - & None & No & No & $\downarrow$ & $\downarrow$ \\
\hline
\end{tabular}




\begin{tabular}{|c|c|c|c|c|c|c|c|c|c|c|c|c|c|c|c|c|}
\hline & al., 2004$)$ & & & & & & & & & & & & & & & \\
\hline \multirow[t]{12}{*}{ Zinc hook } & $\begin{array}{l}\text { S635G (Gatei } \\
\text { et al., 2011) }\end{array}$ & $\mathrm{N}$ & $\mathrm{N}$ & $\mathrm{N}$ & $\mathrm{D}$ & $\mathrm{N}$ & $\mathrm{N}$ & $\mathrm{N}$ & No effect & - & - & None & No & No & $\downarrow$ & $\downarrow$ \\
\hline & $\begin{array}{l}\text { S679R (Roset } \\
\text { et al., } \\
\text { 2014)(Hohl et } \\
\text { al., 2015) }\end{array}$ & $\mathrm{N}$ & $\mathrm{N}$ & $\mathrm{N}$ & $\mathrm{N}$ & $\mathrm{N}$ & $\mathrm{D}$ & $\mathrm{N}$ & No effect & - & - & None & No & No & $\downarrow$ & $\downarrow$ \\
\hline & $\begin{array}{l}\text { C680N (He et } \\
\text { al., 2012) }\end{array}$ & $\mathrm{N}$ & $\mathrm{N}$ & $\mathrm{N}$ & $\mathrm{D}$ & $\mathrm{N}$ & $\mathrm{D}$ & $\mathrm{D}$ & Loss of N-linked glycosylation at N677 & 0.02 & 0.04 & - N-glycosylation site & No & No & $\downarrow$ & $\downarrow$ \\
\hline & $\begin{array}{l}\text { C681A (He et } \\
\text { al., 2012) }\end{array}$ & $\mathrm{D}$ & $\mathrm{D}$ & $\mathrm{D}$ & $\mathrm{D}$ & $\mathrm{D}$ & $\mathrm{D}$ & $\mathrm{D}$ & $\begin{array}{l}\text { Gain of helix } \\
\text { Gain of N-linked glycosylation at N677 }\end{array}$ & $\begin{array}{l}0.30 \\
0.02\end{array}$ & $\begin{array}{ll}8.0 \mathrm{e}-03 \\
0.03 \\
\end{array}$ & - N-glycosylation site & No & No & $\downarrow$ & $\downarrow$ \\
\hline & $\begin{array}{l}\text { C681S } \\
\text { (Barfoot et al., } \\
\text { 2015) }\end{array}$ & $\mathrm{D}$ & $\mathrm{D}$ & $\mathrm{D}$ & $\mathrm{D}$ & $\mathrm{D}$ & $\mathrm{D}$ & $\mathrm{N}$ & Gain of N-linked glycosylation at N677 & 0.02 & 0.04 & $\begin{array}{l}\text { - N-glycosylation site } \\
\text { - Proline-directed phosphorylation } \\
\text { - MAPK phosphorylation site }\end{array}$ & No & No & $\uparrow$ & $\downarrow$ \\
\hline & $\begin{array}{l}\text { P682E } \\
\text { (Roset et al., } \\
\text { 2014) (Hohl et } \\
\text { al., 2015) }\end{array}$ & $\mathrm{D}$ & $\mathrm{D}$ & $\mathrm{N}$ & $\mathrm{D}$ & $\mathrm{D}$ & $\mathrm{D}$ & $\mathrm{D}$ & $\begin{array}{l}\text { Gain of helix } \\
\text { Altered coiled coil } \\
\text { Loss of N-linked glycosylation at N677 }\end{array}$ & $\begin{array}{l}0.32 \\
0.14 \\
0.02\end{array}$ & $\begin{array}{l}3.1 \mathrm{e}-03 \\
0.03 \\
0.04\end{array}$ & - CK2 phosphorylation site & No & No & $\downarrow$ & $\downarrow$ \\
\hline & $\begin{array}{l}\text { P682A (He et } \\
\text { al., 2012) }\end{array}$ & $\mathrm{N}$ & $\mathrm{N}$ & $\mathrm{N}$ & $\mathrm{N}$ & $\mathrm{D}$ & $\mathrm{D}$ & $\mathrm{N}$ & No effect & - & - & None & No & No & $\downarrow$ & $\downarrow$ \\
\hline & $\begin{array}{l}\text { V683I (He et } \\
\text { al., 2012) }\end{array}$ & $\mathrm{N}$ & $\mathrm{N}$ & $\mathrm{N}$ & $\mathrm{N}$ & $\mathrm{N}$ & $\mathrm{D}$ & $\mathrm{N}$ & No effect & - & - & None & No & No & $\uparrow$ & $\uparrow$ \\
\hline & $\begin{array}{l}\text { V683R (Roset } \\
\text { et al., } \\
\text { 2014)(Hohl et } \\
\text { al., 2015) }\end{array}$ & $\mathrm{N}$ & $\mathrm{N}$ & $\mathrm{N}$ & $\mathrm{N}$ & $\mathrm{N}$ & $\mathrm{D}$ & $\mathrm{D}$ & Gain of helix & 0.29 & 0.01 & None & No & No & $\downarrow$ & $\downarrow$ \\
\hline & $\begin{array}{l}\text { C684R (He et } \\
\text { al., 2012) }\end{array}$ & $\mathrm{D}$ & $\mathrm{D}$ & $\mathrm{D}$ & $\mathrm{D}$ & $\mathrm{D}$ & $\mathrm{D}$ & $\mathrm{D}$ & Gain of helix & 0.30 & $9.5 \mathrm{e}-03$ & - Diarginine retention/retrieving signal & No & No & $\downarrow$ & $\downarrow$ \\
\hline & $\begin{array}{l}\text { C684S (Barfoot } \\
\text { et al., 2015) }\end{array}$ & $\mathrm{D}$ & $\mathrm{D}$ & $\mathrm{D}$ & $\mathrm{D}$ & $\mathrm{D}$ & $\mathrm{D}$ & $\mathrm{D}$ & No effect & - & - & $\begin{array}{l}\text { PIKK phosphorylation site } \\
\text { - PKC phosphorylation site }\end{array}$ & No & No & $\downarrow$ & $\downarrow$ \\
\hline & $\begin{array}{l}\text { Q685S (He et } \\
\text { al., 2012) }\end{array}$ & $\mathrm{N}$ & $\mathrm{N}$ & $\mathrm{N}$ & $\mathrm{N}$ & $\mathrm{N}$ & $\mathrm{D}$ & $\mathrm{N}$ & Altered coiled coil & 0.53 & $6.5 \mathrm{e}-03$ & $\begin{array}{l}\text { - BRCT phosphopeptide ligands } \\
\text { - USP7 binding motif }\end{array}$ & No & No & $\downarrow$ & $\downarrow$ \\
\hline \multirow[t]{4}{*}{$\begin{array}{l}\text { Signature } \\
\text { motif }\end{array}$} & $\begin{array}{l}\text { R1198E } \\
\text { (Rojowska et } \\
\text { al., 2014b) }\end{array}$ & $\mathrm{D}$ & $\mathrm{D}$ & $\mathrm{D}$ & $\mathrm{D}$ & $\mathrm{D}$ & $\mathrm{D}$ & $\mathrm{D}$ & $\begin{array}{l}\text { Gain of catalytic site at R1200 } \\
\text { Gain of allosteric site at R1200 } \\
\text { Altered metal binding } \\
\text { Altered transmembrane protein }\end{array}$ & $\begin{array}{l}0.25 \\
0.21 \\
0.14 \\
0.10\end{array}$ & $\begin{array}{l}4.8 \mathrm{e}-03 \\
0.03 \\
0.03 \\
0.04\end{array}$ & - Diarginine retention/retrieving signal & No & No & $\downarrow$ & $\downarrow$ \\
\hline & $\begin{array}{l}\text { G1199E } \\
\text { (Rojowska et } \\
\text { al., 2014b) }\end{array}$ & $\mathrm{D}$ & $\mathrm{D}$ & $\mathrm{D}$ & $\mathrm{D}$ & $\mathrm{D}$ & $\mathrm{D}$ & $\mathrm{D}$ & $\begin{array}{l}\text { Loss of allosteric site at R1200 } \\
\text { Loss of catalytic site at R1200 } \\
\text { Altered transmembrane protein }\end{array}$ & $\begin{array}{l}0.23 \\
0.20 \\
0.11 \\
\end{array}$ & $\begin{array}{l}0.03 \\
0.01 \\
0.04 \\
\end{array}$ & $\begin{array}{l}\text { - Diarginine retention/retrieving signal } \\
\text { - PKA phosphorylation site }\end{array}$ & No & No & $\downarrow$ & $\downarrow$ \\
\hline & $\begin{array}{l}\text { S1202A } \\
\text { (Herdendorf } \\
\text { and Nelson, } \\
2011 \text { ) }\end{array}$ & $\mathrm{D}$ & $\mathrm{D}$ & $\mathrm{D}$ & $\mathrm{D}$ & $\mathrm{D}$ & $\mathrm{D}$ & $\mathrm{D}$ & $\begin{array}{l}\text { Loss of allosteric site at R1200 } \\
\text { Loss of catalytic site at R1200 }\end{array}$ & $\begin{array}{l}0.23 \\
0.20\end{array}$ & $\begin{array}{l}0.03 \\
0.01\end{array}$ & $\begin{array}{l}\text { - PKA phosphorylation site } \\
\text { - -Glycosaminoglycan attachment site }\end{array}$ & No & No & $\downarrow$ & $\downarrow$ \\
\hline & $\begin{array}{l}\text { S1202R } \\
\text { (Koroleva et } \\
\text { al., 2007) } \\
\text { (Moncalian, } \\
\text { Lengsfeld, } \\
\text { Bhaskara, } \\
\text { Hopfner, } \\
\text { Karcher, Alden, } \\
\text { J. A. Tainer, et } \\
\text { al., 2004) } \\
\text { (Herdendorf } \\
\text { and Nelson, } \\
\text { 2011) }\end{array}$ & $\mathrm{D}$ & $\mathrm{D}$ & $\mathrm{D}$ & $\mathrm{D}$ & $\mathrm{D}$ & $\mathrm{D}$ & $\mathrm{D}$ & $\begin{array}{l}\text { Gain of ADP-ribosylation at S1202 } \\
\text { Loss of allosteric site at R1200 } \\
\text { Loss of catalytic site at R1200 }\end{array}$ & $\begin{array}{l}0.25 \\
0.23 \\
0.21\end{array}$ & $\begin{array}{l}8.4 \mathrm{e}-03 \\
0.03 \\
1.0 \mathrm{e}-02\end{array}$ & $\begin{array}{l}\text { - PKA phosphorylation site } \\
\text { - Glycosaminoglycan attachment site }\end{array}$ & No & No & $\uparrow \uparrow$ & $\downarrow$ \\
\hline
\end{tabular}




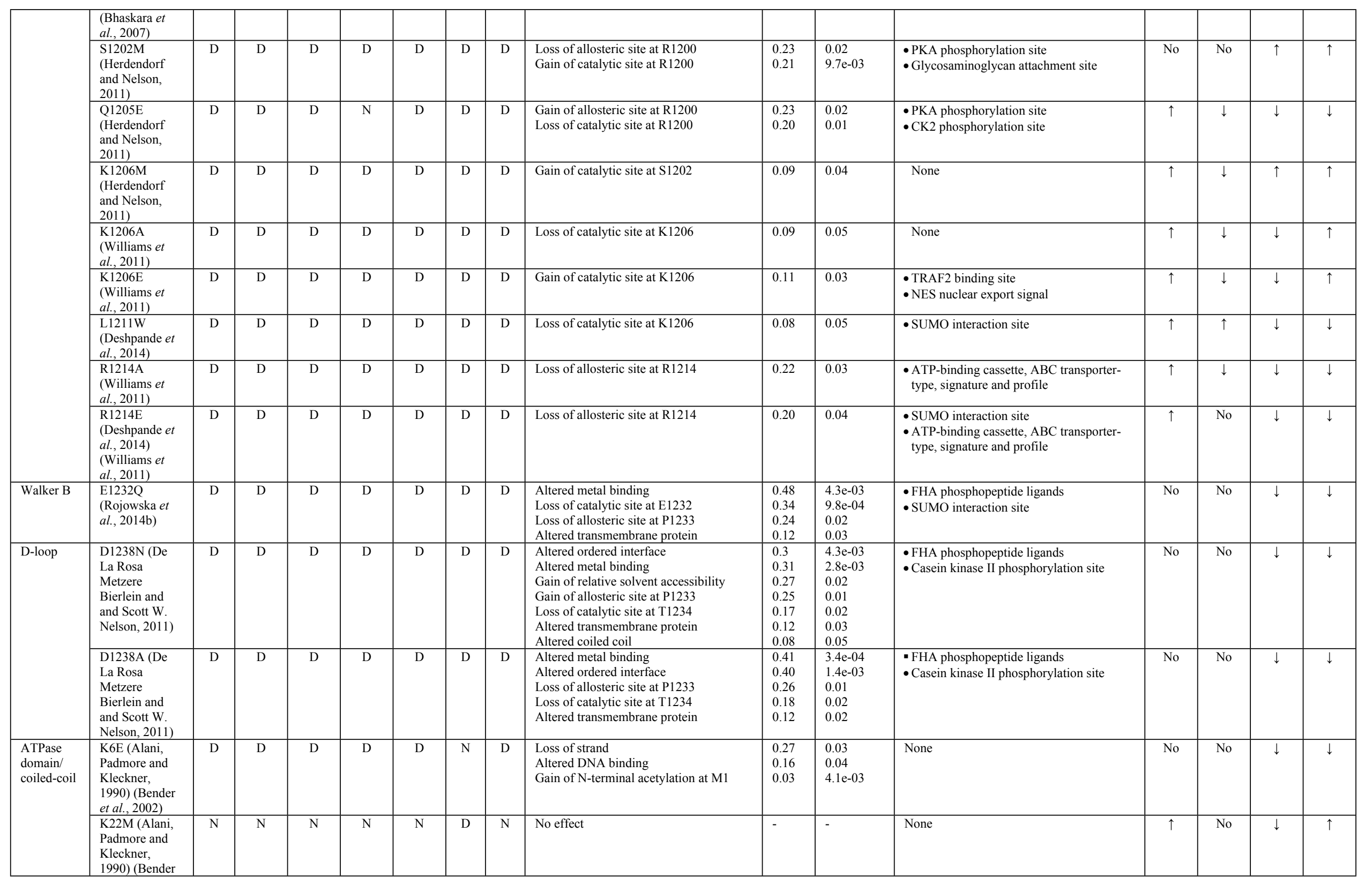




\begin{tabular}{|c|c|c|c|c|c|c|c|c|c|c|c|c|c|c|c|}
\hline et al., 2002) & & & & & & & & & & & & & & & \\
\hline $\begin{array}{l}\text { R83I } \\
\text { (Alani, } \\
\text { Padmore and } \\
\text { Kleckner, } \\
\text { 1990) (Bender } \\
\text { et al., 2002) }\end{array}$ & $\mathrm{N}$ & $\mathrm{D}$ & $\mathrm{N}$ & $\mathrm{N}$ & $\mathrm{N}$ & $\mathrm{D}$ & $\mathrm{N}$ & $\begin{array}{l}\text { Altered ordered interface } \\
\text { Altered DNA binding } \\
\text { Altered coiled coil }\end{array}$ & $\begin{array}{l}0.29 \\
0.22 \\
0.10\end{array}$ & $\begin{array}{l}0.03 \\
0.02 \\
0.04\end{array}$ & •PP1-docking motif RVXF & $\uparrow$ & $\uparrow$ & $\downarrow$ & $\uparrow$ \\
\hline $\begin{array}{l}\text { K132E } \\
\text { (Rojowska et } \\
\text { al., 2014b) }\end{array}$ & $\mathrm{D}$ & $\mathrm{D}$ & $\mathrm{N}$ & $\mathrm{D}$ & $\mathrm{D}$ & $\mathrm{D}$ & $\mathrm{D}$ & $\begin{array}{l}\text { Loss of helix } \\
\text { Altered transmembrane protein } \\
\text { Gain of strand }\end{array}$ & $\begin{array}{l}0.28 \\
0.27 \\
0.27\end{array}$ & $\begin{array}{l}0.02 \\
7.3 \mathrm{e}-04 \\
0.01\end{array}$ & $\begin{array}{l}\text {-CK1 phosphorylation site } \\
\text { - Protein kinase C phosphorylation site }\end{array}$ & No & No & $\downarrow$ & $\downarrow$ \\
\hline $\begin{array}{l}\text { T191E } \\
\text { (Rojowska et } \\
\text { al., 2014b) }\end{array}$ & $\mathrm{N}$ & $\mathrm{D}$ & $\mathrm{N}$ & $\mathrm{N}$ & $\mathrm{N}$ & $\mathrm{N}$ & $\mathrm{N}$ & $\begin{array}{l}\text { Altered coiled coil } \\
\text { Loss of acetylation at K187 }\end{array}$ & $\begin{array}{l}0.28 \\
0.28\end{array}$ & $\begin{array}{l}0.01 \\
6.2 \mathrm{e}-03\end{array}$ & $\begin{array}{l}\text { - TRAF2 binding site } \\
\text { - NEK2 phosphorylation site } \\
\text { - PKC phosphorylation site }\end{array}$ & No & No & $\downarrow$ & $\downarrow$ \\
\hline $\begin{array}{l}\text { C221E } \\
\text { (Rojowska et } \\
\text { al., 2014b) } \\
\end{array}$ & $\mathrm{N}$ & $\mathrm{N}$ & $\mathrm{N}$ & $\mathrm{N}$ & $\mathrm{N}$ & $\mathrm{N}$ & $\mathrm{N}$ & No effect & - & - & None & No & No & $\downarrow$ & $\downarrow$ \\
\hline $\begin{array}{l}\text { K105E } \\
\text { (Rojowska et } \\
\text { al., 2014b) }\end{array}$ & $\mathrm{D}$ & $\mathrm{N}$ & $\mathrm{D}$ & $\mathrm{D}$ & $\mathrm{D}$ & $\mathrm{D}$ & $\mathrm{D}$ & No effect & - & - & None & No & No & $\downarrow$ & $\downarrow$ \\
\hline $\begin{array}{l}\text { S106E } \\
\text { (Rojowska et } \\
\text { al., 2014b) }\end{array}$ & $\mathrm{N}$ & $\mathrm{N}$ & $\mathrm{N}$ & $\mathrm{N}$ & $\mathrm{N}$ & $\mathrm{N}$ & $\mathrm{N}$ & No effect & - & - & None & No & No & $\uparrow$ & $\downarrow$ \\
\hline
\end{tabular}


